\title{
TASAWUF ANTARA PENAFSIRAN NORMATIF DAN SOSIOLOGIS DALAM PEMIKIRAN IBN KHALDŪN
}

\author{
Abdul Kadir Riyadi \\ Universitas Islam Negeri Sunan Ampel Surabaya, Indonesia \\ E-mail: riyadi.abdulkadir@gmail.com
}

\begin{abstract}
This study takes up the challenge of investigating Ibn Khaldūn's concept of tasawuf by relating it to his overwhelming idea of al-Umrān. The man has been widely known for his innovative assessment on various issues relating to society, organization, civilization and above all, forms of knowledge. He has been acknowledged as a pioneer and father of modern sociology. Nonetheless, little has been done to study his thought on Sufism and how this form of knowledge works in social context. Ibn Khaldūn himself has not worked out to explain this problem. But one may reconstruct it within his comprehensive concept of alUmran, which is understood by some as a form of theories on social organization. It is toward this aim that this study is carried out. It argues that in Ibn Khaldūn's mind, tasawuf a) is part and parcel of his notion of social organization without which a society may not emerge; and b) society has its roots not only in material, civilisational and biological needs of both man and society, but also in their spiritual needs. This spiritual need in its turns is the very motives why many undertakes spiritual quest. It is also, socially speaking, the raison de'etre for social cohesion to emerge. Hence, Ibn Khaldūn's sociology of tasawuf as it were, has its epistemological underpinning in his implicit idea of spiritual cohesion in society.
\end{abstract}

Keywords: Ibn Khaldūn; tasawuf; al-'Umrān; solidarity; cohesion.

\section{Pendahuluan}

Menghadirkan Ibn Khaldūn di tengah-tengah kerumunan sosiolog top dunia kini tidak lagi aneh atau sulit. Beberapa dekade lalu, Ibn Khaldūn masih belum terlalu dikenal di dunia Barat. Di dunia Islam, ia sudah dikenal namun kajian terhadapnya tidak terlalu banyak sehingga terkesan terlupakan. Sekarang, sarjana Muslim dan Barat 
berlomba mendalami pemikirannya. Mereka baru menyadari bahwa Ibn Khaldūn menyediakan wacana yang memadai untuk membaca persoalan kontemporer yang menyelimuti dimensi sosial dan keagamaan manusia sekarang ini. Sosok besar dalam kajian sosiologi dan antropologi agama kontemporer seperti Akbar S. Ahmad mengatakan bahwa, "manusia modern harus berterima kasih kepada Ibn Khaldūn" karena jasanya yang tidak ternilai dalam hal pengembangan ilmu pengetahuan dan pembacaan yang tajam terhadap peradaban.

Di ranah sosiologi, kontribusi Ibn Khaldūn tidak terhingga. Tidak sedikit pakar sosiologi Barat yang mengakuinya sebagai bapak sosiologi. Sebut saja Alfred Kremer, Robert Flint, Ludwig Gumplowicz, Rene Maunier, Franz Oppenheimer, Ortega, Piritim Sorokin, Carle Zimmerman, Charles Galphin, Harry Barnes dan Howard Becker. Hampir semua di antara mereka menyebut gagasan Ibn Khaldūn sebagai "ide sosiologi modern dalam menjelaskan persoalan masyarakat". ${ }^{1}$

Di dunia Arab-Islam Ibn Khaldūn yang sempat mengalami penolakan antara lain oleh Ibn Ḥajar al-'Asqalānī-mewakili sarjana era klasik—dan TTāha Ḥusayn-mewakili sarjana kontemporer-kini sudah diakui sebagai pahlawan. Seiring perjalanan waktu, kajian terhadap pemikirannya tidak henti-hentinya dilakukan. Tidak sekadar mengkajinya, pelan tapi pasti kini sarjana Arab-Islam mulai melihatnya dari sudut pandang yang berbeda. Sosok seperti Mahmoud Dhaouadi, Syed Farid Alatas, bahkan mereka yang kritis terhadapnya seperti Muhammad Abdullah Anan dan Mahmūd Ismāīl termasuk dalam golongan ini.

Akses terhadap ilmu pengetahuan yang semakin mudah membuat lalu lintas ilmu kian cepat dan deras, tak terkecuali sosiologi secara umum dan kajian wacana Khaldunian secara khusus. Dibandingkan dengan ilmu lain, sosiologi tergolong ilmu yang berkembang dengan sangat cepat. Kajian wacana Khaldunian diuntungkan dengan perkembangan sosiologi yang cepat ini.

Perkembangan sosiologi-dan di dalamnya pemikiran Ibn Khaldūn - kini menjadi hidangan sehari-hari bagi para ahli di bidang ilmu ini. Bagi yang mengikutinya akan dikagetkan dengan betapa banyaknya literatur di bidang kajian ini. Satu sisi ini positif, namun

1 Lihat Harry Barnes dan Howard Becker, Social Thought: from Lore to Science (Washington: Heath and Company, 1938). 
cepatnya perkembangan ilmu sosiologi dapat pula menimbulkan ketidakpastian. Tidak sedikit di antara para ahli merasa telah "hilang" di tengah belantara sosiologi yang tiada ujung dan tepi. Tidak aneh jika dalam konteks ini, Randall Collins mengatakan bahwa sosiologi adalah tentang "kehidupan intelektual yang membingungkan". ${ }^{2}$

Banyaknya wacana yang simpang-siur membuat gagasan datang dan pergi tanpa henti. Beragam wacana itu kadang menyisakan sedikit ruang bagi usaha pengembangan dan inovasi. Patut diakui bahwa ketika produksi ilmu pengetahuan berjalan terlalu cepat, maka tidak sedikit orang yang justru akan mengalami disorientasi. Ini pada gilirannya menjadi pemicu bagi kejenuhan dan stagnansi.

Betapapun, fenomena ini adalah tantangan dan bukan takdir. Dalam dunia keilmuan, sebuah wacana—apalagi paradigma—sudah seharusnya melahirkan wacana baru. Jika tidak demikian, maka sifat ilmiahnya justru akan dipertanyakan. Dalam kaitan inilah, banyaknya kajian terhadap warisan Ibn Khaldūn dapat dipandang sebagai perkembangan yang positif. Hanya saja, setiap kajian lanjutan haruslah kemudian dilakukan dengan kerangka yang berbeda agar dapat memberikan kontribusi baru.

Inilah yang akan dilakukan dalam pembahasan ini; pemikiran Ibn Khaldūn akan diulas dengan fokus pada ajarannya mengenai tasawuf sebagai bagian dari al-Umrān. Tidak hanya itu, artikel ini melangkah sedikit lebih jauh dengan melakukan penelusuran apakah dalam pemikiran Ibn Khaldūn terdapat benih-benih untuk mengembangkan apa yang kita sebut sebagai sosiologi tasawuf?

\section{Tradisi yang Hilang}

Satu hal yang harus diakui dari Ibn Khaldūn adalah kemampuannya menciptakan gagasan yang mampu bertahan lama dan berhasil memancing perdebatan yang terus berlangsung selama beberapa abad. Ini saja sudah cukup sebagai bukti bahwa pemikirannya layak disanjung sebagai paradigma yang mapan yang tidak lekang dimakan waktu. Bukti lain yang menjadikan gagasannya layak diapresiasi adalah, kemunculannya kembali setelah sempat terkubur beberapa abad.

2 Randall Collins, The Sociology of Philosophies: A Global Theory of Intellectual Change. Edisi keempat (Cambridge, Massachusetts dan London: The Belknap Press of Harvard University Press, 2002), 1. 
Tidak banyak yang tahu bahwa pemikiran Ibn Khaldūn sejatinya mengalami pasang surut dan bahkan pernah dinyatakan hilang. Penyataan "hilang" setidaknya datang dari dua sumber yang sangat dipercaya dalam ranah kajian wacana Khaldunian, yaitu Mohammed Abdullah Enan (w. 1986) dan Syed Farid Alatas. Enan adalah pakar sejarah Andalusia asal Mesir. Ia sarjana yang sangat produktif. Dalam satu kesempatan, Enan mengungkapkan bahwa, "pemikiran Ibn Khaldūn dilupakan di Timur dan warisan intelektualnya nyaris dilemparkan ke keranjang sampah". ${ }^{3}$ Enan mencatat bahwa dunia Arab-Islam baru menyadari pentingnya Ibn Khaldūn sejak tahun 1932, setelah "himbauan disebarkan untuk menghidupkan kembali pemikirannya" pada kesempatan peringatan 600 tahun kelahirannya. ${ }^{4}$ Sementara itu Alatas menggambarkan pemikiran Ibn Khaldūn sebagai "The Lost Tradition" (Tradisi yang Hilang) dan menggunakan istilah ini sebagai judul bagi satu karyanya tentang Ibn Khaldūn. ${ }^{5}$ Jika Enan yang kita jadikan patokan, dan tahun 1932 kita ambil sebagai pedoman akan "lahirnya kembali Ibn Khaldūn" berarti bangsa ArabIslam sangat telat mengenalnya. Ini sangat disayangkan mengingat "relevansi dan modernitas pemikiran Ibn Khaldūn yang sangat tinggi", meminjam istilah Enan.

Sejak kemunculannya, wacana Khaldunian memang menuai banyak pro dan kontra. Berbeda dengan sosoknya yang bisa diterima di hampir semua lini kehidupan, pemikiran Ibn Khaldūn ternyata cukup kontroversial pada masanya. Sebagai pribadi, Ibn Khaldūn sudah dikenal secara luas. Ia bahkan mendapat tempat yang terhormat di kalangan penguasa dan ulama. Namun sejak mengundurkan diri dari dunia politik, dan fokus menulis karya, ia menjadi sosok yang berbeda. Pada masa hidupnya, tidak banyak yang dapat menerima gagasannya. Bahkan tidak banyak pula yang rela menjadi sahabatnya. Penelusuran yang dilakukan oleh Robert Irwin menunjukkan bahwa selama keberadaannya di Mesir-persisnya setelah beralih profesi sebagai penulis_-Ibn Khaldūn hanya memiliki dua orang teman, yaitu

\footnotetext{
${ }^{3}$ Muhammad Abdullah Enan, Biografi Ibn Khaldūn: Kehidupan dan Karya Bapak. Sosiologi Dunia, terj. Machnun Husein (Jakarta: Zaman, 2013), 7.

${ }^{4}$ Ibid

${ }^{5}$ Lihat Syed Farid Alatas, Applying Ibn Khaldun: The Recovery of a Lost Tradition in Sociology (London dan New York: Routledge, 2014).
} 
Taqiy al-Dīn al-Maqrizī (w. 1442), dan Muḥammad Ibn 'Ammar (w. 1441). ${ }^{6}$

Beberapa abad setelah wafatnya masih banyak pula orang yang ingin menolaknya dan tidak sudi menjadi "sahabatnya". Di era modern ini, daftar nama yang menolak gagasannya sangatlah panjang. Di antara mereka ada tiga nama yang patut diperhitungkan, yaitu Ṭāha Husayn (w. 1973), Enan dan Maḥmūd Ismāīl (w. 1983). Tiga orang ini bukan sosok biasa dalam sejarah pemikiran Islam. Mereka sudah diakui secara luas sebagai otoritas di bidang ilmunya masing-masing. Apa yang mereka katakan tentang Ibn Khaldūn turut mewarnai perkembangan wacana Khaldunian secara khusus dan khazanah pemikiran Islam secara umum.

Taha Hussein disepakati sebagai salah satu pemikir Mesir terhebat sepanjang masa. J Jalāl al-'Ațīyah menyebutnya sebagai "asrama ilmu pengetahuan". Ia juga mendapat julukan sebagai, "pemuka sastra Arab" ("amid al-adab al-'Arabi). Terhadap Ibn Khaldūn, Husayn tidak saja menunjukkan sikap penolakannya, namun juga terkesan sangat keras menilainya. Tidak seperti ilmuan pada umumnya, Husayn mengkaji pemikirannya dan sekaligus mengungkit kepribadiannya. Baginya, Ibn Khaldūn adalah sosok yang cacat moral karena ambisi politiknya yang berlebihan. ${ }^{9}$ Husayn menulis disertasinya di Universitas Sorbonne tentang Ibn Khaldūn di bawah bimbingan, antara lain Emile Durkheim, salah satu bapak ilmu sosiologi modern. Di Mesir secara khusus dan dunia Islam secara umum, pembacaan Husayn terhadap Ibn Khaldūn yang kontroversial sudah menjadi fokus kajian tersendiri. Pandangannya telah beranak-pinak dan melahirkan banyak perdebatan. ${ }^{10}$

Sikap Husayn dilanjutkan bahkan dipertajam oleh Enan. Sosok ini memiliki kedekatan emosional tersendiri baik dengan Ḥusayn maupun dengan Ibn Khaldūn. Enan menerjemahkan disertasi Ḥusayn dari

${ }^{6}$ Robert Irwin, Ibn Khaldun: an Intellectual Biography (Princeton: Princeton University Press, 2018), 103-104.

7 Abdel Fattah Galal, "Taha Hussein”, Prospect: The Quarterly Review of Comparative Education, Vol XXIII, No 3/4 (1993), 687-710.

8 Jalāl al-'Ațīyah, "Ṭaha Ḥusayn wa Ibn Khaldūn fī Qafas al-Ittihām”, al-Sharq alAwsat, 1 November, edisi 9470 (2004).

9 Syed Farid Alatas, Ibn Khaldun (Oxford: Oxford University Press, 2012), 20.

${ }^{10}$ Contoh perdebatan yang muncul adalah yang terjadi antara Hasan Ahmad Jagham yang membela Taha Hussein dan Abū al-Qāsim Karo yang membela Ibn Khaldūn. Lihat al-'Ațiyah, "Ṭaha Husayn". 
Bahasa Perancis ke dalam Bahasa Arab. ${ }^{11}$ Dengan demikian, ia memiliki rasa hormat yang tinggi terhadap Husayn, tokoh lulusan alAzhar yang liberal ini. Sementara itu, terhadap Ibn Khaldūn, Enan juga merasa dekat. Ia bahkan menganggap dirinya sebagai murid intelektualnya. ${ }^{12}$

Enan bukan sosok yang gemar berada di bawah bayang-bayang pendahulunya. Ia juga berhasil membangun reputasinya sendiri terutama di bidang ilmu sejarah. Karyanya yang sangat monumental tentang sejarah Andalusia membuatnya dikenal luas sebagai otoritas di bidang ilmu ini. 'Umar Mustafā Luṭî́ sampai menyebutnya sebagai "sejarawan ensiklopedis yang lengkap". ${ }^{13}$ Karya ini terdiri dari tujuh volume dan menyerupai ensiklopedia. Ia butuh waktu 25 tahun untuk menyelesaikannya.

Pandagannya tentang Ibn Khaldūn ia tuangkan dalam satu karya berjudul Ibn Khaldūn: Hayātuh wa Turäthuh al-Fikrī. Karya ini sudah diterjemahkan ke dalam Bahasa Inggris dan terbit di Pakistan pada tahun 1975, lalu di India pada tahun 1979 dan terakhir di Malaysia pada tahun 2007. Edisi Bahasa Indonesia juga sudah tersedia dengan judul Biografi Ibn Khaldūn dan terbit pada tahun 2013. Hanya saja, edisi Bahasa Indonesia ini merupakan terjemahan dari edisi Bahasa Inggris, bukan Bahasa Arab. Jadi sifatnya, terjemahan atas terjemahan.

Walau Enan menunjukkan kedekatannya dan bahkan rasa hormat terhadap Ibn Khaldūn, namun itu sama sekali tidak menghalangi dirinya untuk bersikap kritis terhadapnya. Tesis besar yang ingin ia kembangkan adalah bahwa pemikiran Ibn Khaldūn tidak baru, melainkan kelanjutan dari pemikiran al-Fārābī.

Sementara itu, Maḥmūd Ismāīl adalah sosok yang tidak kalah unik. Ismāil tumbuh dan berkembang sebagai pakar ilmu sejarah dan peradaban yang sangat disegani. Dalam sebuah kesempatan, Hasan Hanafi-filsuf Mesir kontemporer-mengaku bahwa Ismāīl lebih hebat dari dirinya. Ismāīl telah melahirkan banyak sekali karya antara lain—dan yang paling penting—adalah Süsiyülujȳya al-Fiker al-Islämi

11 Lihat Țaha Husayn, Falsafah Ibn Khaldūn al-Ijtimāiàyas: Tạ̣lī wa Naqd, terj. Muhammad 'Abd Allah Enan (Mesir: Mațba'at al-I'timād, 1925).

12 Enan, Biografi Ibn Khaldūn, 8. Lihat juga Muhammad Abdullah Enan, Ibn Khaldūn: His Life and Works (Kuala Lumpur: The Other Press, 2007), 3.

13 'Umar Mustafāà Luṭī, "Muhammad 'Abd Allah Enan”, Majalah Hilāl, Edisi Januari (1985). 
(Sosiologi Pemikiran Islam), yang terdiri dari empat jilid. ${ }^{14}$ Buku ini menegaskan Ismāīl sebagai penganut aliran sosialisme-marxisme. Karena karya inilah—ditambah dengan karyanya yang lainpemikiran Ismāīl kini sudah diakui sebagai aliran tersendiri dalam ilmu sosiologi dengan nama al-Madrasah al-Mahmüdìyah. Pandangannya tentang Ibn Khaldūn ia tuangkan dalam sebuah karya yang cukup provokatif berjudul Nihäyah Ustūrah (Akhir sebuah Mitos). Dalam karya ini, Ismāīl berargumen bahwa klaim Ibn Khaldūn akan kebaruan ilmu yang ia ciptakan adalah khayalan belaka. Baginya, karya Ibn Khaldūn tidak lain adalah jiplakan atas gagasan Ikhwān al-Ṣafā. ${ }^{15}$

Apa yang dilakukan oleh tiga sosok ini mengingatkan kembali akan seorang figur yang sangat kritis terhadap Ibn Khaldūn, bernama Ibn Ḥajar al-'Asqalānī, tokoh legendaris dan pakar kenamaan di bidang ilmu ḥadīth. Al-'Asqalānī tidak saja menolak pandangan Ibn Khaldūn, tapi juga menuduhnya sesat. Apa yang dilakukan oleh al'Asqaān̄i dapat dikatakan sebagai-meminjam istilah filsafat ilmusebuah falsifikasi, yaitu usaha menyalahkan dan memangkas perkembangan sebuah wacana. Untuk beberapa saat, falsifikasi al'Asqaāān̄ ini berhasil. Terbukti, wacana Ibn Khaldūn gagal berkembang dan harus menunggu selama kurang lebih 600 tahun untuk kembali dikenal di dunia Arab-Islam.

Al-'Asqaāānì sendiri adalah raksasa ilmu hadìth, dan penulis Fath al-Bari yang sangat melegenda. Pengaruh besarnya dan kedigdayaan kitab ini rasanya sudah cukup sebagai bukti bahwa al-'Asqalānì dapat menggalang dukungan dari sarjana Islam lintas generasi untuk menolak Ibn Khaldūn dan bahkan meminggirkannya.

Ali al-Wardī, seorang pakar sosiologi asal Irak tidak ragu mengkaitkan hilangnya wacana Khaldunian dengan pengaruh al'Asqalānī. ${ }^{16}$ Penelusuran al-Wardī menunjukkan bahwa al-'Asqalānī memang secara sengaja menghadang Ibn Khaldūn. Alasannya, karena yang bersangkutan merupakan penganut-bahkan pernah mengaku keturunan-Shī'ah Fāṭimīyah. Aliran ini sesat dan berbahaya secara politis dan teologis, menurut al-'Asqalānī. Mereka "fanatik dan gemar mencemooh sahabat Nabi. Beberapa pemimpin mereka bahkan

\footnotetext{
${ }^{14}$ Untuk karya ini lihat Maḥmūd Ismāîl, Sūsiyūlujìyā al-Fiker al-Islāmì (London, Beirut, Kairo: Sinā li al-Nashr, 2000).

15 Alatas, Ibn Khaldun.

16 'Alī al-Wardī, Mantiq Ibn Khaldūn fì Ḍaw' Hadāratih wa Shakhshìyatih (Beirut: Dār Kufan, 1994), 228.
} 
mengaku sebagai Tuhan". ${ }^{17}$ Al-'Asqalān̄̄ lalu menegaskan bahwa pandangan teologis aliran ini adalah sebab utama mengapa orang seperti Ibn Khaldūn "harus dihindari". ${ }^{18}$

Ibn Khaldūn sendiri tidak pernah menanggapi penilaian al'Asqalānī kepadanya. Bisa jadi karena tidak berdaya atau mungkin juga karena tidak sempat melakukannya. Yang pasti kritik terhadap pemikirannnya dibiarkan mengalir dan pelan-pelan menggerogoti keberadaannya.

Kritik dan bahkan ujian berat karena tuduhan sesat juga menimpa beberapa pengikutnya yang jumlahnya tidak seberapa. Tercatat, Ibn Khaldūn memiliki tiga pengikut yang siap membelanya. Namun pembelaan itu gagal dikarenakan beberapa hal, antara lain: 1) otoritas ulama figh dan hadīth yang lebih kuat, 2) umat Islam secara umum sedang menghadapi kejumudan keilmuan yang ditandai dengan, a) sikap fanatik terhadap ilmu tertentu terutama figh, b) keengganan menerima kehadiran ilmu baru seperti yang diusung oleh Ibn Khaldūn, dan c) sikap taklid, yaitu mengikuti pandangan tertentu secara buta. Karena alasan inilah, dengan mudah gagasan Ibn Khaldūn tertolak.

Beberapa nama yang tercatat sebagai pengikut Ibn Khaldūn adalah sosok-sosok penting yang memiliki otoritas sendiri di bidangnya terutama sejarah. Sebut saja Taqiy al-Dīn al-Maqrizī dan Abū 'Abd Allah Muhammad b. 'Alī b. Muhammad al-Asbahī atau yang lebih populer dengan sebutan Ibn al-Azraq (w. 1491). Di samping itu ada pula nama Muhammad Ibn 'Ammar. Namun ia tidak terlalu populer dan tidak memiliki pengaruh yang berarti baik secara akademik, sosial maupun politik.

Al-Maqrizī adalah murid langsung Ibn Khaldūn. Ia berguru kepadanya saat Ibn Khaldūn menetap di Mesir dan menduduki jabatan penting di sana sebagai jaksa agung dan guru besar di Madrasah Qamhīyah. Al-Wardī mencatat bahwa al-Maqrizī sangat mengagumi Ibn Khaldūn dan terkesan dengan keluasan ilmu dan wawasannya. ${ }^{19}$

Al-Maqrizī lahir dan besar di Mesir. Ia pakar di bidang ilmu sejarah dan ekonomi. Pemikirannya hingga kini masih digandrungi oleh banyak kalangan dan terus dikaji secara luas. Ia menulis banyak

17 Ibid.

${ }^{18}$ Ibid.

${ }^{19}$ Ibid. 
buku, konon jumlahnya mencapai 200 karya di berbagai bidang ilmu pengetahuan. Beberapa karyanya sudah diterjemahkan ke dalam bahasa asing terutama Bahasa Perancis. Yang paling terkenal dari ratusan karyanya adalah Muqaffa, sebuah buku ensiklopedis yang membahas mengenai sejarah Mesir. Buku ini terdiri dari 16 jilid, namun diakui oleh al-Sakhawī bahwa sesungguhnya jika ditulis hingga selesai buku ini dapat mencapai 80 jilid. ${ }^{20}$

Pengaruh Ibn Khaldūn dalam Muqaffa sudah nampak. Sentuhan filosofis terlihat menonjol di dalamnya. Walau buku ini mirip sebagai buku sejarah pada umumnya, namun nuansa Muqaddimah sangat kental di dalamnya. Karena itu jika Muqaffa yang dijadikan ukurannya, maka tidak dapat dipungkiri al-Maqrizī adalah anak intelektual Ibn Khaldūn.

Dalam banyak karyanya yang lain, al-Maqrizi tidak saja menunjukkan kegemilangannya sebagai pemikir yang menonjol namun juga berusaha membantu "mengabadikan" warisan Ibn Khaldūn. Ia umpama menulis Ighäthat al-Ummah bi Kashf al-Ghummah (Menyikap Tabir untuk Menyelematkan Umat). Di sini wajah Ibn Khaldūn tergambar sangat nyata.

Igāthah adalah buku tentang fenomena sejarah, sosial dan ekonomi yang terjadi pada masa penulisnya. Buku ini tidak saja tentang sejarah secara umum, melainkan juga tentang peristiwa tertentu pada masa tertentu yang disajikan secara kritis dan melalui "proses telaah yang mendalam", demikian tulis al-Maqrizi sendiri. ${ }^{21}$ Dalam buku ini ia tidak saja bicara sebagai sejarawan yang sekadar menarasikan atau mencatat sebuah peristiwa. Ia juga membuat skema, menyajikan Analisa, dan mengetengahkan kritik. Buku ini dilihat dari judulnya mengandung keresehan yang mendalam. Igäthah adalah semacam teriakan minta tolong atas krisis (ghummab) yang dihadapi oleh masyarakat Mesir kala itu. Krisis yang dimaksud adalah fenomena kelaparan parah yang terjadi kala itu. Melihat materi pembahasannya, buku ini adalah karya pertama di dunia yang secara khusus membahas tentang fenomena kelaparan dalam sebuah masyarakat.

Dalam Ighäthah, al-Maqrizī mengajukan kritik terhadap pemerintah yang ia tuding lalai. Pemerintah—ia katakan—harus bertanggung

\footnotetext{
20 Tentang karya ini, lihat Taqiy al-Dīn al-Maqrizī, al-Muqaffa al-Kabìr, Muhammad 'Uthmān (ed.) (Beirut: Dār al-Kutub al-Ilmīyah, 2005).

21 Taqiy al-Dīn al-Maqrizī, Ighäthat al-Ummah bi Kashf al-Ghummah, Karām Hịlmī Farhat (ed.) (Kairo: ‘Ayn, 2007), 15.
} 
jawab karena ia tidak saja pemegang kebijakan namun juga sebagai penyebab utama terjadinya kelaparan ini. Karena pendapat ini, alMaqrizi dipenjarakan dan diisolasi dari masyarakat. ${ }^{22}$ Para kritikus yang tidak sependapat dengannya, antara lain karena afiliasinya dengan Ibn Khaldūn, semakin leluasa meminggirkannya.

Karya lain yang sangat Khaldunian adalah al-Mawäriz wa al-I tibär. Karya ini-dibandingkan dengan karyanya yang lain-paling kental dengan nuansa Khaldunian. Dari judulnya saja sudah terlihat pengaruh gurunya terhadapnya dan langsung mengingatkan pada karya Ibn Khaldūn berjudul al-Tbar. Demikian pula dengan pembahasannya. Buku ini bicara mengenai apa yang al-Maqrizī sebut sebagai peradaban (al-umrān) Mesir dengan perhatian khusus pada aspek ekonomi, sosial dan keagamaan. Istilah al-umrän sendiri adalah ciptaan Ibn Khaldūn dan merupakan pokok bahasannya dalam Muqaddimah. Dengan pertimbangan ini maka sulit untuk dibantah bahwa al-Maqrizī adalah representasi dari Ibn Khaldūn, dan salah satu "tangannya" yang bekerja untuk mengendalikan wacana Khaldunian pada masanya. ${ }^{23}$

Al-Maqrizī sangat mengagumi Muqaddimah. Ia menilai buku ini sebagai sumber dari segala ilmu pengetahuan. Ia menulis, Muqaddimah adalah "pokok dari segala pengetahuan, bentuk dari kehebatan akal pikiran manusia. Buku ini menyampaikan narasi tentang kejadian dan peristiwa, dan bicara tentang simbol-simbol keberadaan di dunia dengan gaya yang lebih jenius dari mutiara yang bercahaya, dan lebih segar dari air jernih yang tertiup angin sepoi-sepoi basah". ${ }^{24}$

Walau sebagai murid Ibn Khaldūn, al-Maqriz̄̄ adalah pemikir yang mandiri. Ia memang tersinari oleh cahaya ilmu gurunya, dan merasakan segarnya air jernih yang dihasilkannya. Namun ia tidak pernah dibesarkan di bawah bayang-bayangnya. Ia berhasil menciptakan reputasinya sendiri dan di kemudian hari terkesan lepas dari pengaruhnya. Dengan ungkapan lain, mata rantai yang menghubungkan antara Ibn Khaldūn dan al-Maqrizī terasa terputus. Putusnya mata rantai ini adalah akibat dari antara lain usaha sistematis

\footnotetext{
22 al-Wardī, Mantiq Ibn Khaldūn, 78.

23 Terkait dengan hubungan antara Ibn Khaldūn dan al-Maqrizī lihat Irwin, Ibn Khaldun. Lihat juga Nasser Rabbat, "Was al-Maqrizīs Khitat a Khaldunian History?", Der Islam, Vol. 89, No. 1-2 (November 2012).

${ }^{24}$ Dikutip dari Irwin, Ibn Khaldun, 103.
} 
dan disengaja para kritikus untuk menghilangkan warisan Ibn Khaldūn.

Di luar Mesir, ada seorang pemikir hebat dan pakar fiqh dari Andalusia yang memiliki perhatian besar terhadap Ibn Khaldūn. Kekagumannya bahkan melebihi siapapun termasuk al-Maqrizī. Namanya-seperti yang sudah kita sebut di atas-Ibn al-Azraq. Tidak seperti al-Maqrizī, Ibn al-Azraq tidak pernah ketemu dengan Ibn Khaldūn. Ia lahir pada tahun 1427 atau 21 tahun setelah kematian Ibn Khaldūn. Ia adalah generasi terakhir yang menyaksikan keruntuhan kekhalifahan Islam di Andalusia.

Walau dipisahkan jarak dan waktu, al-Azraq adalah orang yang paling dekat dengan Ibn Khaldūn secara psikologis. Tercatat ia adalah orang pertama yang memberikan perhatian sangat besar terhadap Muqaddimah. Ibn al-Azraq menulis kitab berjudul Badā' ${ }^{\prime}$ al-Silk fi Tabä ${ }^{\prime}$ al-Mulk (Perilaku Terhomat para Penguasa). ${ }^{25}$ Karya ini merupakan usaha untuk mengumpulkan pandangan para pendahulunya tentang perilaku para pembesar dalam berpolitik. Namun di balik itu, apa yang ia lakukan sejatinya adalah ikhtiar untuk menjaga dan melestarikan pemikiran Ibn Khaldūn. Dalam karya ini, ia menghidupkan lagi wacana Ibn Khaldūn terutama teorinya tentang kekuasaan dan masyarakat yang kala itu terancam akan mati. Namun sayang, gaung pemikiran Ibn al-Azraq gagal menggema dan gendang perjuangannya pupus secepat angin lalu lagi-lagi karena kuatnya arus penolakan terhadapnya.

Usaha mengabadikan pemikiran Ibn Khaldūn terputus selama lebih dari satu abad setelah kematian Ibn al-Azraq pada tahun 1491. Selama masa itu, di dunia Islam-Arab nyaris tidak ada orang yang peduli dengan Ibn Khaldūn dan pemikirannya. Ia benar-benar terlupakan dan menghilang dari peredaran. Sejauh yang dapat diketahui barulah pada tahun 1609, lahir seorang pemikir yang memiliki perhatian besar kepadanya. Namanya Haji Khalīfah dari Turki, atau yang lebih dikenal dengan sebutan Kātib Halabī.

Haji Khalifah bukan seorang sarjana yang dididik dan dibesarkan dalam lingkungan madrasah, layaknya para ilmuan lainnya. Ia belajar secara otodidak atau kadang belajar secara privat kepada para gurunya. Beberapa nama yang termasuk dalam daftar gurunya adalah Imam Isa

${ }^{25}$ Untuk karya ini lihat Abū 'Abd Allah b. al-Azraq, Badā'i' al-Silk fi Ṭabā’’' al-Mulk, 'Alī Sāmī al-Nashshār (Kairo: Dār al-Salām, 1990). 
Halife, Imam Ilyas Hoca, dan Bogru Ahmed Celebi. Dari nama-nama ini, tidak ada yang memiliki perhatian khusus kepada Ibn Khaldūn.

Pengaruh Ibn Khaldūn terhadap Haji Khalīfah sangat besar dan jelas. Itu nampaknya adalah hasil dari pencariannya sendiri. Dalam beberapa karyanya, ia tidak saja rajin menyebut namanya namun juga mengutip dan membahas pemikirannya. Ia adalah penulis karya yang sangat monumental berjudul Kashf al-Zunün 'an Asam al-Kutub wa alFunūn (Menyikap Keraguan Mengungkap Nama-nama Buku dan Ilmu Pengetahuan).$^{26}$ Dalam karya ini, pengaruh Ibn Khaldūn sangat kental sebagaimana ia akui sendiri. Dengan melihat karya ini, beberapa pengkaji dari Eropa seperti Bernard Lewis, Oliver Leaman, Antony Black, Kate Fleet dan masih banyak lagi yang lainnya menyebut Haji Khalīfah sebagai pewaris Ibn Khaldūn yang sesungguhnya. ${ }^{27}$

Haji Khalīfah sendiri adalah sosok pemikir yang progresif. Mungkin sebagian orang akan menilainya terlalu kebarat-baratan. Ia melihat tanda-tanda kemajuan peradaban di Eropa pada satu sisi, dan alamat kemunduran peradaban Islam pada sisi lain. Untuk membangun peradaban Islam, ia mengajukan tawaran yang kala itu sangat mengguncang, yaitu "umat Islam Turki Usmani harus belajar dan mencontoh Eropa dalam hal pembaharuan pendidikan dan pengembangan ilmu pengetahuan".

Adanya beberapa nama besar yang menjadi penerus gagasan Ibn Khaldūn nampaknya tidak membuat Ibn Khaldūn dikenal luas di dunia Islam-Arab untuk beberapa saat. 'Alī al-Wardī-seperti yang sudah kita singgung-menganut tesis bahwa Ibn Khaldūn sempat menghilang dan terlupakan. Tesis yang sama dianut oleh beberapa peneliti Barat seperti Lewis dan Leaman. Lewis tidak ragu mengatakan bahwa "yang berjasa menemukan kembali Ibn Khaldūn adalah kesarjanaan Barat". ${ }^{28}$ Ia melanjutkan, seolah merendahkan kesarjanaan

\footnotetext{
${ }^{26}$ Untuk karya ini lihat Haji Khalīfah Mustafā b. 'Abd Allah Kātib Halabi, Kashf alZunūn 'an Asam al-Kutub wa al-Funūn, 'Abd al-Qādir 'Ațā' (ed.) (Beirut: Dar al-Kutub al-Ilmīyah, 2006).

${ }^{27}$ Lihat Bernard Lewis, "Ibn Khaldun in Turkey", dalam Jesus Viguera Mollins (ed.), Ibn Khaldun: The Mediterranean in the 14th Century (Rise and Fall of Empires) (Andalusi: Jose Manuel Lara, 2006), 376. Lihat juga S. Leyla Gurkan, "Celebi, Katib Mustafa b Abdullah", dalam Oliver Leaman (ed.), The Biographical Encyclopeia of Islamic Philosophy (London: Bloomsbury, 2014), 349. Lihat juga Antony Black, History of Islamic Political Thought (Edinburg: Edinburg University Press, 2011). Lihat juga Kate Fleet, The Cambridge History of Turkey, Suraiya N. Faroqhi (ed.) (Cambridge: Cambridge University Press, t.th.).

${ }^{28}$ Lewis, "Ibn Khaldun in Turkey", 376.
} 
Arab-Islam, bahwa di kala oleh bangsanya sendiri Ibn Khaldūn dilupakan, ia justru dihargai oleh para sarjana Barat. "Setelah kurang lebih 300 tahun sejak kematiannya, adalah Barat-persisnya Parisyang untuk pertama kalinya menerbitkan Muqaddimah dalam edisi Bahasa Arab pada tahun 1858", tulis Lewis. ${ }^{29}$

Ini adalah sisi kelam dari sejarah kesarjanaan Islam-Arab. Namun Lewis ternyata tidak selamanya benar setidaknya di mata Antony Black. Black membantah dan mengatakan bahwa dua abad sebelum Barat mengenal Ibn Khaldūn, Haji Khalīfah sudah terlebih dulu menghidupkannya kembali dan memperkenalkannya kepada dunia modern. Hanya saja mungkin kala itu pemikiran Haji Khalifah belum sampai ke telinga para pemikir Barat.

Yang patut dicatat di sini adalah, bahwa perhatian sarjana ArabIslam terhadap Ibn Khaldūn memang tergolong minim. Itu jelas memprihatinkan. Walau kajian terhadapnya memang ada, namun jumlah dan kualitasnya tidak sebanding dengan kaliber yang ia miliki. Di samping pengaruh al-'Asqalānī yang begitu besar terhadap peminggiran Ibn Khaldūn, keterpurukan Islam sebagai kekuatan politik dan peradaban dunia jelas menjadi faktor yang sangat menentukan. Hilangnya tradisi Ibn Khaldūn untuk beberapa saat bisa berarti bahwa ia memang tidak dikehendaki. Atau bisa juga berarti bahwa pemikirannya terlalu maju sehingga saat itu tidak ada orang yang mengerti dan memahaminya.

\section{Penafsiran Normatif atas Tasawuf}

Pandangan Ibn Khaldūn tentang tasawuf termasuk yang rentan terhadap penolakan dan pada gilirannya mudah untuk dikucilkan. Betapa tidak, ia hadir pada saat para sufi seperti sarjana lainnya sedang mengalami kebuntuan akademik dan cenderung bersifat tertutup. Dengan mudah mereka akan menolak kritik yang dialamatkan kepada tasawuf dan para sufi. Pada sisi lain, para sufi pada masa ini bisa jadi masih sensitif dan trauma terutama dengan kritik Ibn Taymìah yang hampir melumpuhkan tasawuf. Pada masa Ibn Khaldūn, perkembangan tasawuf tergolong tersendat setelah sempat mengalami kemajuan pesat pada masa Abū Hāmid al-Ghazālī. Hadirnya Ibn 'Arabī pasca-al-Ghazāî̀ nampaknya justru membuka pintu luas bagi para kritikus untuk melayangkan sengatan mematikan. Para sufi yang

${ }^{29}$ Ibid. 
berada pada posisi bertahan, tidak dapat berbuat banyak kecuali berdiam diri atau balik menghujat.

Tidak ada catatan yang memuaskan mengenai apa yang terjadi dengan wacana Ibn Khaldūn mengenai tasawuf setelah digulirkan. Bisa jadi, kelemahan bahkan ketakmampuan para sufi pada masa ini untuk berwacana membuat perdebatan mengenai tasawuf Khaldunian menjadi sepi dan hening. Pada satu sisi, ada kesan seolah Ibn Khaldūn dibiarkan dengan bebas menari sendirian di atas panggung tanpa ada satupun orang yang menontonnya. Ini tidak menarik. Ini menjadi pentas solo yang sia-sia tanpa hadirin dan tentu tanpa tepuk tangan. Jika ada kata yang tepat untuk melukiskan pendapat Ibn Khaldūn tentang tasawuf, maka kata itu adalah "sepi" dan "hening".

Ibn Khaldūn sendiri bukanlah seorang sufi, juga bukan penggiat ilmu tasawuf. ${ }^{30}$ Pandangannya tentang tasawuf akan dengan mudah ditolak oleh para sufi karena subjektif. Ia tidak memiliki afiliasi apapun dengan tarekat atau dengan kelompok sufi tertentu. Memang wawasannya tentang tasawuf cukup luas, layaknya seorang sarjana yang mumpuni. Ia paham dengan baik ajaran beberapa tokoh sentral tasawuf seperti al-Muhāasibī, al-Qushayrī dan al-Ghazālī. Hanya ini yang membuatnya dianggap "dekat" dengan tasawuf dan sebagian tokoh sufi.

"Kedekatan" Ibn Khaldūn dengan tasawuf dan para sufi tergambar juga dari cara ia dimakamkan. Konon, para sufi-lah yang terlibat dalam prosesi pemakamannya ketika ia meninggal. Ia pun dimakamkan di pemakaman para sufi di Kairo. Namun anehnya, di antara kuburan para sufi itu, makam Ibn Khaldūn secara pasti tidak diketahui. ${ }^{31}$

Membaca Muqaddimah maka akan memberikan kesan bahwa tasawuf sangat menarik perhatiannya dan menjadi salah satu fokus pemikirannya. Ia menyediakan ruang khusus untuk pembahasan mengenai ilmu ini. Sikapnya positif, namun tidak jarang pula ia kritis. Secara garis besar, ia nampak membedakan antara tasawuf sebagai sistem pemikiran dan sistem tindakan atan tarekat. Sebagai sistem

30 Ada beberapa pihak yang menganggap Ibn Khaldūn sebagai sufi. Lihat Miya Syrier, "Ibn Khaldūn and Islamic Mysticism", Islamic Culture, Vol. 21 (1947), 264302. Lihat juga James Winston Morris, "An Arab Machiavelli? Rhetoric, Philosophy, and Politics in Ibn Khaldūn's Critique of Sufism", Harvard Middle Eastern and Islamic Review, Vol. 8 (2009), 264.

31 Khālid al-'Aț̣ār, "Kata Pengantar", Muqaddimab Ibn Khaldūn (Beirut: Dār al-Fikr, 1998), 5. 
pemikiran ia masih membedakan lagi antara tasawuf sunnī dan falsafī. Ia memang tidak pernah menggunakan isitlah ini, namun pola argumentasinya mengarah ke sana. Ia menerima tasawuf sunnī dengan beberapa catatan, dan menolak tasawuf falsafì secara keseluruhan. Sementara itu, terhadap tarekat ia juga menolak salah satu ajaran yang sudah sangat populer di kalangan para pengikut tasawuf sunnī, yaitu konsep kemurshidan. Jadi, berkaitan dengan tasawuf falsafì ia secara total menolaknya. Namun untuk tasawuf sunnī, ia menolak sebagian dan menerima sebagian yang lain. Ia menulis:

Jalan para sufi terdiri dari dua jenis: yang pertama adalah jalan Sunnah, jalan yang ditempuh oleh para pendahulu yang sesuai dengan al-Qur'ān dan Sunnah, meniru perilaku para pendahulu seperti para sahabat dan pengikut Nabi. Jalan yang kedua dicemari oleh bid'ah, yaitu jalan para sufi akhir (muta'akkbirün) yang menjadikan jalan pertama sebagai cara penyingkapan. Termasuk di antara mereka adalah Ibn 'Arabī, Ibn Sab'īn, Ibn Barrajan, dan para pengikut mereka yang menempuh banyak perjalanan dan melakukan ibadah sesuai dengan aliran mereka sendiri (niḅlab). Mereka menulis banyak karya yang dipenuhi dengan ajaran kesesatan dan bid'ah serta penafsiran terhadap ajaran-ajaran agama yang mereka anggap bersifat lahiriah. Penafsiran mereka sungguh aneh, tidak berdasar dan melenceng. Siapapun yang membaca karya mereka akan langsung mengerti bahwa ajaran mereka itu tidak sesuai dengan shari ${ }^{-6} a{ }^{32}$

Pada kutipan di atas, Ibn Khaldūn bicara mengenai tasawuf sebagai sebuah sistem pemikiran. Ia sama sekali tidak keberatan dengan tasawuf sunnī. Ia bahkan menunjukkan sikap positif terhadapnya. Pandangannya yang positif tentang tasawuf sunnī secara khusus dan tasawuf secara umum bahkan ia matangkan lagi dalam Muqaddimah pada bab pertama dan bab 6, pembahasan ke 17. Di sini ia menganggap tasawuf sebagai bagian dari peradaban. Ilmu yang satu ini dalam pandangannya turut berperan dalam membangun kemajuan dengan jalur pengetahuan. ${ }^{33}$

Dalam bab pertama, ia membahas tasawuf bersamaan dengan pembahasan mengenai "kelompok orang yang memiliki pengetahuan gaib”. Ibn Khaldūn menempatkan kenabian sebagai jenis ilmu gaib yang paling penting. Kegunaan dan fungsinya dalam struktur peradaban manusia sangat jelas; nabi adalah manusia unggulan dengan

\footnotetext{
${ }^{32}$ Ibn Khaldūn, Shifä' al-Säil (Istanbul: t.tp., 1985), 110.

${ }^{33}$ Ibn Khaldūn, Muqaddimah (Beirut: Dār al-Fikr, 1998), 101.
} 
kemampuan lengkap yang meliputi keunggulan sosial, kepribadian, moral, pengetahuan, keimanan dan fisik. Wawasan dan kesadaran spiritualnya membantunya membentuk pola dan struktur peradaban yang ideal. Nabi juga-meminjam istilah Weber-memiliki otoritas berlapis seperti karisma, intelektual, dan moral yang membuatnya mumpuni tidak saja dalam mengendalikan masayarakatnya namun juga dalam mempersiapkan pengikutnya menghadapi masa depan.

Ibn Khaldūn menyebut unsur-unsur penting yang dimiliki oleh seorang nabi yang membantunya membangun peradaban, seperti mukjizat, ilmu, dan kepribadian yang unggul. Mukjizat yang paling agung yang pernah diturunkan kepada seorang nabi tiada lain adalah al-Qur'ān. ${ }^{34}$ Kitab suci ini tidak saja membawa berita tentang alam gaib yang tidak dapat ditangkap oleh indra, namun juga memberi pentunjuk bagaimana manusia seharunya bertindak agar tercipta kehidupan yang lebih damai, tenteram, sejahtera, dan makmur. Seperti para filsuf pada umumnya, Ibn Khaldūn mengerti bahwa dunia ini terdiri dari alam empiris dan meta-empiris. Pada keduanya, al-Qur'ān memiliki konsep yang jika dipahami dan dikembangkan dapat membawa kemajuan bagi manusia.

Kondisi jiwa yang suci atau fitrah, ditengarai oleh Ibn Khaldūn sebagai modal utama bagi seorang nabi tidak saja dalam proses interaksinya dengan sesama manusia namun juga dengan Tuhannya. Adalah kondisi fitrah ini yang memungkinkan seorang nabi menjadi siap secara mental dan intellektual untuk menerima wahyu. Kesiapan diri ini penting, karena wahyu turun selalu dalam keadaan sulit dan berat. $^{35}$

Fitrah membedakan nabi dengan dukun (kähin). Ibn Khaldūn menjelaskan bahwa dukun, seperti nabi, memiliki kecenderungan untuk menapaki tangga demi tangga hingga sampai pada alam yang lebih tinggi. ${ }^{36}$ Hanya saja, nabi menuju alam malakùt dengan petunjuk dari Tuhan, sedangkan dukun menuju alam gaib dengan dukungan dari setan. Dukun tidak memiliki jiwa yang suci, sehingga motif utamanya dalam pergaulan dengan sesama manusia maupun dengan

\footnotetext{
${ }^{34}$ Ibid., 103.

35 Dalam al-Qur'ān terdapat ayat yang menunjukkan beratnya menerima wahyu seperti surah al-Muzammil ayat 5 .

${ }^{36}$ Ibn Khaldūn, Muqaddimah, 107.
} 
wujud yang gaib adalah kebanggan diri dan kesombongan. Dengan demikian, perdukunan adalah antitesis dari kenabian. ${ }^{37}$

Selain kelompok nabi dan dukun, ada pula empat kelompok lain yang tergolong memiliki ilmu gaib. Mereka adalah, a) kelompok penerawang atau paranormal, b) ahli astrologi, c) al-'arräfün, yaitu para penerka yang berbicara atau memberi nasehat atas dasar dugaan dan perkiraan, bukan atas dasar agama atau ilmu pengetahuan yang sahih, dan d) para penyihir yang secara khusus disebut oleh Ibn Khaldūn banyak ditemukan di wilayah India. Keempat kelompok ini ditambah dengan dukun tidak ada yang selaras dengan kenabian dan dengan demikian berada pada posisi yang berseberangan dengannya.

Para sufi masuk dalam kelompok terakhir yang mendapat apresiasi dari Ibn Khaldūn. ${ }^{38}$ Ditegaskan bahwa mereka memiliki tujuan yang selaras dengan kenabian yaitu tauhid, pengesaan Tuhan secara mutlak. ${ }^{39}$ Mereka mengejar pengetahuan tentang Tuhan dengan cara ibadah dan zikir yang intensif dan berkelanjutan. Sebagian dari mereka berada pada jalur yang benar karena menjalankan perintah agama sesuai tuntunan sharī'ah. Bahkan di antara mereka ada yang meraih derajat kekhususan dan dianugerahi karämah. ${ }^{40}$ Ibn Khaldūn menerima konsep karāmah walau ia sadar di kalangan ulama banyak sekali yang menolaknya seperti Abū Ishāa al-Isfarāyinī dan Abū Muḥammad b. Abī Zayd al-Mālikī.

Di luar kelompok sufi yang disebutkan di atas, Ibn Khaldūn mengakui ada jenis lain dari sufi yang ia sebut bablül. ${ }^{41}$ Ia keberatan dengan mereka. Kelompok ini adalah penganut aliran filosofis dalam tasawuf. Mereka menyerupai orang gila. Pandangan dan perilakunya tidak masuk akal. Kelompok ini antara lain mengajarkan-dan seringkali mengaku telah mencapai—derajat kewalian. Ibn Khaldūn sendiri sesungguhnya menerima kewalian dan bahkan membelanya dari kritik para ulama fiqh. Ia bahkan mengatakan, "para pakar fiqh salah ketika mengatakan kewalian hanya dapat diraih dengan ibadah. Tuhan punya kuasa untuk memberikan anugerah-Nya kepada siapa

\footnotetext{
37 Yang menarik dalam teori Emile Durkheim, Clifford Geertz, Jonathan Smith, Anthony John dan masih banyak lagi yang lainnya, sihir dianggap sebagai unsur paling penting dalam agama.

${ }^{38}$ Ibn Khaldūn, Muqaddimah, 107-115.

${ }^{39}$ Ibid.

40 Karämah dapat diartikan sebagai perkara luar biasa di luar nalar manusia sebagai anugerah dari Tuhan yang dimiliki oleh seseorang selain nabi dan rasul.

${ }^{41}$ Ibn Khaldūn, Muqaddimah, 116.
} 
saja yang Ia kehendaki". ${ }^{42}$ Ia melihat kewalian sebagai kekhususan yang dimiliki oleh seseorang karena Tuhan memang memberinya. ${ }^{43}$

Hanya saja, bagi Ibn Khaldūn kelompok sufi bablül ini tidak berkaitan dengan konsep kewalian dan tidak memiliki akses kepadanya. Ia berpandangan, selama seorang sufi memiliki jiwa yang bersih, ia bukan saja berada pada jalur agama yang benar tapi juga berpeluang mendapat anugerah dari Tuhan. Sufi bablül tidak demikian. Mereka, a) meninggalkan zikir dan ibadah. Jika ibadah, mereka melakukannya tidak sesuai dengan aturan shari $\left.{ }^{-} a h, b\right)$ mereka bodoh sedari awal diciptakan, berbeda dengan orang gila yang menjadi gila setelah waras, dan c) sering bertindak baik dan jahat di tengah masyarakat dengan standar dan cara mereka sendiri dan bukan dengan standar agama. ${ }^{44}$ Hingga titik ini, posisi Ibn Khaldūn terhadap tasawuf sudah dapat dibaca. Ia menerima atau menolak tergantung tasawuf apa yang ia bicarakan.

Pandangannya tentang peran tasawuf dalam peradaban juga dapat dibaca. Ia menyadari bahwa peradaban manusia tidak saja bersifat empiris tapi juga meta-empiris. Unsur kedua ini adalah wilayah, a) kenabian yang ditunjang dengan wahyu dan mukjizat, dan b) tasawuf yang didukung dengan karamah dan kewalian. Dalam sepanjang sejarah manusia, keempat unsur ini (wahyu dan mukjizat, karämah dan kewalian) adalah faktor paling penting dan mendasar dalam membangun dan menjaga peradaban. Ini sangat jelas dalam kasus Islam dan bahkan dalam agama atau peradaban Timur. Peradaban Barat modern yang kini sedang berada pada puncak kemajuannya justru mendatangkan bencana bagi umat manusia karena tidak memiliki keempat unsur meta-empiris itu. Akibatnya, manusia modern menjadi "nestapa" meminjam istilah Seyyed Hossein Nasr, ${ }^{45}$ atau bahkan "sekarat" meminjam istilah T.S Eliot. ${ }^{46}$

\footnotetext{
42 Ibid., 117.

43 Ibid.

44 Ibid. Menurut James Winston Morris ungkapan tentang tiga ciri sufi bablül ini tidak ada dalam semua edisi Muqaddimah. Beberapa edisi tidak menyebutnya. Salah satu edisi yang menyebutnya adalah terbitan Paris tahun 1858 editan EM Quatremere. Lihat Morris, “An Arab Machiavelli?”, 281.

${ }^{45}$ Lihat Seyyed Hossein Nasr, Islam and the Plight of Modern Man (Chicago: ABC International Group, 2001).

${ }^{46}$ Lihat Mariwan Nasradeen Hasan Barzinji, The Image of Modern Man in T.S Eliot's Poetry (Bloomington: Authorhouse, 2012).
} 
Pada bagian lain dalam Muqaddimah, Ibn Khaldūn berbicara tentang tasawuf sebagai syarat dan prasyarat bagi peradaban pada tataran empiris bukan gaib. Tesis besarnya adalah bahwa, a) ilmu dan pendidikan atau pengajaran merupakan syarat alami bagi kemajuan peradaban, b) pengajaran ilmu adalah industri, c) perkembangan ilmu tergantung pada kemajuan sebuah peradaban. ${ }^{47}$ Dengan demikian ilmu dan peradaban tidak dapat dipisahkan. Peran ilmu adalah untuk memajukan peradaban pada dimensi empirisnya. Sebaliknya, peradaban ketika maju dan besar akan dapat memfasilitasi kemajuan dan perkembangan sebuah ilmu. Peradaban yang lemah tidak dapat melahirkan atau mengembangkan sebuah ilmu.

Ibn Khaldūn menyebut ilmu al-Qur'ān dan tafsir pada urutan pertama dalam daftar ilmu pengetahuan yang dibutuhkan oleh sebuah peradaban. Tasawuf ia tempatkan pada urutan ke $11 .{ }^{48}$ Yang menarik adalah dalam daftar ilmu ini ia tidak menyebut ilmu sejarah dan filsafat, padahal ia adalah seorang filsuf dan sejarawan. Bahkan pada aliena paling pertama dalam Muqaddimah ia menekankan pentingnya ilmu sejarah untuk membangun sebuah peradaban. ${ }^{49}$

Posisi Ibn Khaldūn terhadap tasawuf tetap sama dengan yang ia tunjukkan pada bagian awal dalam Muqaddimah. Ia setuju pada satu persoalan, tapi menolak pada persoalan yang lain. Secara mendasar ia mempercayai bahwa tasawuf adalah ilmu yang bertujuan mulia dan sejalan dengan ajaran dasar agama. Kezuhudan adalah salah satu jalan yang ditempuh oleh para sufi untuk mencapai derajat kesempurnaan diri. Tasawuf termasuk dalam kategori ilmu intuitif (idräke li al-aḥwāt) dan bukan ilmu kognitif (idräk li al-ma'ärif). Kedua jenis ilmu ini benar dan dibutuhkan dalam sebuah peradaban. Ilmu kognitif berasal dari pemahaman terhadap bukti dan fakta (adillab), sedangkan ilmu intuitif dari pengalaman. Jika pada bagian awal Muqaddimah, Ibn Khaldūn

\footnotetext{
${ }^{47}$ Ibn Khaldūn, Muqaddimah, 412-416.

48 Berikut daftar ilmu yang dimaksud, 1) ilmu al-Qur’ān dan tafsir, 2) ilmu hadith, 3) ilmu fiqh, 4) ilmu waris, 5) usulul figh, 6) ilmu kalam, 7) pemikiran, 8) ilmu-ilmu eksperimental, 9) ilmu kemanusiaan dan kemalaikatan, 10) ilmu sejarah para nabi, 11) ilmu tasawuf, 12) ilmu tafsir mimpi, 13) ilmu-ilmu rasional, 14) ilmu berhitung, 15) ilmu arsitektur, 16) ilmu konstruksi, 17) ilmu logika, 18) ilmu alam, 19) ilmu kedokteran, 20) ilmu pertanian, 21) ilmu ketuhanan, 22) ilmu sihir, 23) ilmu huruf, dan 24) ilmu kimia.

${ }^{49}$ Ibn Khaldūn, Muqaddimah, 15. Persoalan mengapa ia tidak menyebut ilmu sejarah dan filsafat dapat diangkat dalam penelitian tersendiri, dan tidak dapat dibahas secara khusus pada kesempatan ini.
} 
mengatakan bahwa tujuan akhir dari tasawuf adalah tauhid, maka pada bagian ini ia menambahkan satu lagi, yaitu makrifah.

Ibn Khaldūn mengisyaratkan bahwa tasawuf sebagai ilmu untuk pertama kali lahir di tangan al-Muhạāibib. ${ }^{50}$ Setidaknya ia menyebut tokoh ini dalam urutan pertama sufi yang mengembangkan tasawuf sebagai ilmu. Dalam pandangannya, tasawuf al-Muhāsibī mengajarkan wara', yaitu sikap rendah hati dan menghindarkan diri dari kemewahan duniawi. Tasawuf lalu dikembangkan oleh al-Qushayrī dan alSuhrawardī dengan konsepnya tentang etika bertarekat. Kemudian disempurnakan oleh al-Ghazālī melalui mahakaryanya berjudul Ihya $\bar{a}$ 'Ulüm al-Din. Di tangan tokoh yang terakhir ini, tasawuf menjadi ilmu yang paradigmatik ( 'ilm mudawwan). ${ }^{51}$

Selain keempat tokoh itu, masih banyak lagi sufi yang memiliki kontribusi dan peran unik dalam mengembangkan tasawuf. Siapa saja mereka dapat dilihat dari daftar yang dibuat oleh al-Qushayrī dalam alRisalah. Bagi Ibn Khaldūn, mereka yang masuk dalam daftar adalah sufi yang sesungguhnya. Selain mereka, ia meragukan. Termasuk kategori yang ia ragukan adalah mereka yang ia sebut sebagai alMuta'akekirūn (sufi generasi akhir).

Secara garis besar, sufi generasi akhir adalah mereka yang muncul setelah era al-Qushayrī dan al-Ghazālī. Mereka pada umumnya menganut paham tasawuf filosofis. Ajaran mereka ia sebut aneh, dan sangat aneh. Termasuk dalam ajaran mereka adalah kashf, ḅulül, waḅdat al-wujūd, tajalli, dan ḅudūr. Ibn Khaldūn menolak semua ajaran itu, dan menyebutnya sebagai penyebab kekacauan dan-kasus bulūl dan buudūr-penyebab dibunuhnya al-Hallāj. Ibn Khaldūn mendukung sikap para pakar fiqh yang memerintahkan hukuman mati terhadap alHallāj.

Pembahasan mengenai al-Hallaj pada satu sisi dan tasawuf filosofis pada sisi lain sayangnya menjadi bumerang bagi Ibn Khaldūn bukan karena substansi pembahasannya melainkan karena ia terkesan melanggar teorinya sendiri. Pertama, ia menggagas apa yang ia sebut sebagai "sufi generasi akhir". Masalahnya adalah jika ada sufi akhir, berarti ada pula sufi awal. Jika sufi akhir muncul setelah era alGhazālī, berarti sufi awal adalah yang muncul sebelum era itu. Kedua, Ibn Khaldūn menekankan bahwa corak tasawuf sufi akhir adalah

50 Ibid., 463. Posisi ini pula yang diambil oleh Abdul Kadir Riyadi dalam Arkeologi Tasawuf. Lihat Abdul Kadir Riyadi, Arkeologi Tasawuf (Bandung: Mizan, 2016).

${ }^{51}$ Ibn Khaldūn, Muqaddimah, 463-464. 
filosofis. Persoalannya adalah, tasawuf filosofis sudah lahir jauh sebelum kemunculan sufi awal terutama di tangan al-Hallāj . Artinya, baik sufi akhir atau sufi awal sesungguhnya sama-sama memilki corak filosofis, sebagaimana corak sunnī juga kental dalam ajaran keduanya. Dengan pertimbangan ini, maka klasifikasi Ibn Khaldūn berikut kriterianya tidak selamanya benar.

Terlepas dari itu, bisa jadi Ibn Khaldūn lebih menitikberatkan pada pemikiran sufi akhir yang bercorak filosofis dan berusaha keras untuk menolaknya karena pengaruh besar tiga serangkai yang ia anggap berbahaya. Mereka adalah Ibn 'Arabī (w. 1240), Ibn Sab'īn (w. 1270), dan Ibn Barrajan (w. 1141). Tasawuf sunnī pada masa ini sedang redup, dan digantikan dengan tasawuf filosofis yang sedang naik daun. Untuk beberapa wilayah seperti Andalusia, tasawuf sunnī tidak berkembang. Ini agak aneh mengingat era ini hanya berjarak beberapa dekade saja dari al-Ghazālī yang berhasil melambungkan tasawuf sunnī dan memangkas laju tasawuf filosofis. Ketiga tokoh di atas berada di balik perkembangan yang mencengangkan ini.

Sikap Ibn Khaldūn terhadap tasawuf filosofis menyerupai Ibn Taymìyah. Pandangannya yang ekstrem dapat disimak dari kutipan sebagai berikut:

Di antara para sufi itu, ada Ibn 'Arabī, Ibn Sab'īn, dan Ibn Barrajan dan orang-orang yang mengikuti jejak mereka serta mengambil ajarannya. Mereka menulis banyak karya dan diedarkan di antara mereka sendiri. Karya-karya ini mengusung keyakinan palsu dan mengajarkan bid'ah. Usaha apapun untuk menjelaskan pandangan mereka hanya akan menunjukkan bahwa pandangan itu keliru dan salah kaprah. Sikap kita terhadap karya-karya ini dan yang sejenisnya adalah: ketika ditemukan, karya-karya ini harus dihancurkan dengan cara dibakar atau dibuang ke laut sehingga jejak-jejaknya tidak dapat dilihat sama sekali. ${ }^{52}$

Tidak sampai di sini saja. Ibn Khaldūn juga menunjukkan sikap apatisnya terhadap tasawuf filosofis melalui Shifä' al-Säil Jawaban untuk Penanya). Karya ini ia tulis pada tahun 1374 sebelum penulisan Muqaddimah konon atas permintaan Abū Ishāq al-Shātibī (w. 1388) seorang pakar fiqh, penulis al-Muwāfaqät dan penggagas konsep maqāsid al-sharíab. Al-Shāțibī juga memiliki sikap yang kritis terhadap tasawuf dan selalu diresahkan dengan persoalan perlu tidaknya seorang murshid bagi pelaku tasawuf. Misi Shifä' adalah memaparkan

52 Dikutip dari Allan James Fromherz, Ibn Khaldun: Life and Times (Edinburg: Edinburg University Press, 2010), 126 
pokok ajaran tasawuf sunnī sekaligus mengajukan kritik terhadapnya terutama mengenai konsep kemurshidan dan mengajukan penolakan tegas atas ajaran tasawuf filosofis..$^{53}$

Pada aspek normatif, apa yang dijelaskan dalam kitab ini tidak jauh berbeda dengan yang ditemui dalam kitab-kitab tasawuf pada umumnya. Ajaran-ajaran dasar tasawuf diuraikan secara deduktif, mengutip beberapa sumber yang sudah otoritatif. Cara ini ditempuh karena untuk menjawab pertanyaan yang normatif pada satu sisi, dan untuk menjaga keaslian ajaran tasawuf pada sisi lain. Pembahasan mengenai perlu tidaknya seorang murshid dalam tasawuf atau tarekat menjadi ruh dalam kitab ini. Setelah berselancar jauh dan mendalam, Ibn Khaldūn sampai pada kesimpulan bahwa murshid sama sekali tidak diperlukan baik dalam tasawuf maupun dalam kehidupan sehari-hari. Dengan tegas ia menekankan bahwa, "agama diturunkan bukan untuk membawa berkah (melalui murshid) melainkan untuk membawa maslahah" ${ }^{54}$

Sementara itu pendirian Ibn Khaldūn terhadap tasawuf filosofis tetap tidak berubah dalam kitab ini. Ia nampaknya tidak segan untuk mengatakan bahwa tasawuf filosofis tidak saja berpotensi melupakan konsep maslahah seperti yang terjadi dalam kasus kemurshidan, namun juga akan mengikisnya dan kemudian menghanyutkannya.

\section{Tasawuf dan Solidaritas Spiritual}

Persoalah perlu tidaknya seorang murshid dalam tasawuf ternyata sangat sensitif pada masa hidup Ibn Khaldūn. Karena persoalan ini, sering terjadi percekcokan antara para ulama fiqh dan sufi. Ibn Khaldūn sendiri sejatinya lebih gusar dengan persoalan pintu ijtihad yang konon sudah ditutup dari pada memikirkan masalah kemurshidan ini. Pada masa ini, setiap pakar fiqh harus menegaskan afiliasinya kepada salah satu mazhab. Tanpa afiliasi ini, dia tidak dianggap sebagai pakar fiqh. Dengan keharusan adanya afiliasi ini, seorang ulama fiqh hanya bisa mengambil pendapat imam mazhabnya dan tidak dibenarkan melakukan ijtihad di luar garis mazhab.

53 Syed Farid Alatas merangkum kritik Ibn Khaldūn terhadap tasawuf filosofis sebagai berikut: a) konsep waḅdat al-wujūd sama dengan ajaran Kristen mengenai Yesus dan Shī'ah mengenai keimaman, b) konsep tajalli (manifestasi Tuhan) tidak dapat dipahami karena rancu, c) konsep wali kutub bertentangan dengan logika, d) konsep penyingkapan tidak masuk akal, dan e) perilaku mabuk bertentangan dengan shari'`ah. Lihat Alatas, Ibn Khaldun, 93.

${ }^{54}$ Alatas, Ibn Khaldun, 126-128. 
Kelemahan fiqh ini sesungguhnya menjadi kelebihan bagi tasawuf. Dalam tasawuf tidak ada mazhab. Maka dengan mengatakan bahwa "kemurshidan tidak dibutuhkan dalam tasawuf" Ibn Khaldūn sesungguhnya bermaksud menyelamatkan tasawuf dari fanatisme sektoral yang dialami oleh figh.

Dalam kitab Shifä' al-Sä̀l, Ibn Khaldūn bicara mengenai akar kemunculan tasawuf dan sejarah perkembangannya. Juga tentang berbagai macam aliran yang ada di dalamnya. Ia bicara mengenai ajaran tasawuf yang sejalan dengan al-Sunnah dan yang bertentangan dengannya. Yang menarik adalah bahwa Ibn Khaldūn memahami tasawuf tidak saja secara nomatif namun juga historis. ${ }^{55}$ Secara normatif, Ibn Khaldūn memperlakukan tasawuf sebagai kepanjangan dari shari ${ }^{-} a h$. Islam tidak bisa hanya diamalkan secara zahir saja. Ada orang tertentu yang ingin mencapai derajat batin yang tidak dapat ditemukan dalam dimensi zahir sharíah. Tasawuf lahir untuk memenuhi hasrat para pelaku kezuhudan yang ingin mencapai derajat makrifat. Jalan tasawuf ini dapat dibenarkan selama tidak bertentangan dengan sharī'ah seperti yang diajarkan oleh al-Muhạasibī, al-Qushayrī, dan al-Ghazālī.

Keselarasan tasawuf dengan agama dapat dilihat dari ajaran tiga sufi di atas. Menurutnya, ajaran mereka sudah sangat ideal bagi para pencari kebenaran dan kezuhudan. Ajaran al-Muhạsibī berkisar pada persoalan "mujāhadah takwa", yaitu berpegang teguh pada aturanaturan Tuhan, menjalankan perintah-perintah-Nya dan menghindari segala larangan-Nya; ajaran al-Qushayrī berkisar pada persoalan "mujāhadah istikamah", yaitu usaha mencari kebenaran untuk mendapatkan kebahagiaan dengan cara mengikuti akhlaq al-Qur'ān secara penuh; sedang ajaran al-Ghazālī menggabungkan keduanya dan menghasilkan "mujāhadah pencerahan".

Sementara itu secara historis, Ibn Khaldūn menawarkan setidaknya dua tesis tentang bagaimana tasawuf lahir. Pertama, ia lahir karena kecenderungan manusia terhadap alam nyata dan alam gaib. ${ }^{56}$ Manusia memiliki kecenderungan alami untuk kembali kepada alam gaib tanpa harus meninggalkan alam empiris. Kedua, tasawuf lahir karena perasaan kecewa terhadap perkembangan yang terjadi di dunia

\footnotetext{
55 Mengenai analisis historis atas pemikiran Ibn Khaldūn tentang tasawuf, lihat Ali Omlil, al-Khitāōb al-Tārìkhi: Dirāsab li Manhajīyat Ibn Khaldūn (Beirut: Ma'had al-Inmā' al-'Arabī, 1997).

${ }^{56}$ Ibid., 167.
} 
Islam baik pada tataran keilmuan maupun peradaban. Dinasti Mamlūk di Mesir pada masa Ibn Khaldūn berada pada jurang kehancuran. Dinasti ini memiliki tanda-tanda kemunduran seperti yang ada pada dinasti-dinasti lainnya pada era pos-Mongolian. ${ }^{57}$ Salah satu tanda kemunduran itu adalah kegemaran hidup mewah, lupa pada fungsi manusia yang sesungguhnya sebagai khalifah untuk membangun dunia tanpa harus mengesampingkan akhirat.

Dengan membaca fakta-fakta sejarah, Ibn Khaldūn menganggap tasawuf sebagai respons positif terhadap realita sosial yang memprihantinkan. Tasawuf mengajak kepada kezuhudan namun tidak berarti mendukung atau mendorong kepada kepasifan. Tasawuf lahir dan berkembang pada saat peradaban Islam mencapai puncak kejayaannya. Para pemikir sufi yang paling menonjol pun hidup pada masa kejayaan ini.

Tasawuf juga mewakili dimensi moral masyarakat dan turut mencanangkan kaidah interaksi antara manusia dan Tuhan, dan manusia dengan sesama manusia. Tujuannya tidak lain adalah membangun masyarakat berdasarkan nilai-nilai luhur moralitas dan kebaikan. Tidak ada yang salah dengan tasawuf. Kegagalan peradaban Islam pada masa tertentu adalah kesalahan kolektif umat Islam yang terjadi karena kemandulan intelektual.

Selain aspek normatif dan historis, pemikiran Ibn Khaldūn tentang tasawuf juga diyakini memiliki dimensi sosiologis. Ini tidak aneh karena ia adalah sosok yang diakui sebagai "bapak sosiologi modern". Namun sebagai catatan, analisis sosiologis atas pemikirannya mengenai tasawuf sejauh ini belum banyak dilakukan. Para pakar yang memiliki perhatian besar terhadap teori sosial Ibn Khaldūn dan pandangannya mengenai tasawuf tidak terlalu serius menyeledidiki dimensi sosial tasawuf ini. 'Abd al-Ghanī Maghribī, seorang sarjana asal Irak yang meluangkan banyak waktu untuk mengungkap "Pemikiran Sosial Ibn Khaldūn", sempat memberi harapan akan melakukannya. Namun dengan sangat mengecewekan, ia justru hanya berkata bahwa kitab Shifä' al-Säil yang membahas ilmu tasawuf "adalah kitab di bidang ilmu sosial agama". ${ }^{58}$ Setelah itu, dia diam dan tidak berbuat apa-apa.

\footnotetext{
${ }^{57}$ Morris, “An Arab Machiavelli?”, 244.

58 'Abd al-Ghanī Maghribī, al-Fiker al-Ijtimā' ind Ibn Khaldūn (Aljazair: Diwan alMaṭū'at al-Jāmi'îyah, 1988), 30.
} 
Para sarjana Barat yang piawai dalam ilmu sosiologi, sebut saja Ernest Gellner sejauh ini juga belum banyak membantu. Dalam Muslim Society ia sebatas bicara mengenai fenomena sosial tasawuf dalam konteks sosiologi agama, dan bukan sosiologi tasawuf secara konseptual.

Untungnya sudah banyak yang melakukan kajian atas pemikiran Ibn Khaldūn secara makro dalam konteks sosiologi agama atau sosiologi umum. Dari sinilah kita sedikit terbantu untuk menelaah pemikiran sosiologi tasawuf Ibn Khaldūn. Yang dapat kita manfaatkan dari kajian-kajian ini adalah menarik teori sosiologi Ibn Khaldūn ke wilayah spiritualitas, atau mengosongkannya dari muatan sosial untuk kemudian diisi dengan muatan tasawuf. Peneliti seperti Alatas pernah mencoba menggagas "sosiologi tasawuf" ala Ibn Khaldūn namun dalam konteks sosiologi pengetahuan. Ia mencatat bahwa, "yang dilakukan oleh Ibn Khaldūn terkait dengan tasawuf adalah bagian dari tipe sosiologi yang ia usung. Kritiknya terhadap tasawuf mengandung informasi mengenai pandangan dan pendekatannya terkait dengan dimensi sosial suatu ide dan gagasan". ${ }^{59}$

Yang kita coba gagas di sini bukanlah sosiologi pengetahuan melainkan sebuah sosiologi yang mengkaji persoalan masyarakat atau kelompok, pola-pola hubungan dan interaksi sosial yang terjadi di dalamnya dengan fokus utama pada masyarakat atau kelompok sufi. Pendekatan sosiologi yang kita gagas ini bisa saja menggunakan metode penelusuran empiris, namun yang diutamakan di sini adalah metode analisis-kritis atas wacana Ibn Khaldūn secara khusus dan wacana lain yang relevan. Dalam konteks wacana Ibn Khaldūn, tidak ada cara lain yang lebih baik untuk mengulas persoalan ini kecuali dengan melihat konsepnya tentang al-Umrān berikut dua tema besar di dalamnya, yaitu peradaban dan pembaruan ilmu pengetahuan.

Al-Umrän sendiri adalah lembaga yang kental dengan nuasan sosial. Di dalamnya terdapat unsur-unsur yang bersifat sosialkemasyarakatan seperti budaya, kekuasaan, politik dan organisasi sosial. Al-Umrān sering diartikan sebagai peradaban namun ada juga yang mengartikannya sebagai organisasi sosial atau masyarakat. ${ }^{60}$ Bagi Ibn Khaldūn, peradaban, organisasi sosial dan masyarakat adalah satu keharusan. Ia adalah struktur yang tanpanya tujuan hidup manusia

\footnotetext{
59 Alatas, Ibn Khaldun, 89.

${ }^{60}$ Syed Farid Alatas termasuk yang memaknai al-Umrān sebagai organisasi sosial. Lihat Alatas, Applying Ibn Khaldun.
} 
tidak dapat diwujudkan. Tanpanya pula rencana Tuhan untuk menjadikan manusia sebagai khalifah tidak dapat tercapai. Dalam struktur ini ada nilai, sistem dan hukum salah satunya adalah asabiyah yang sering diartikan sebagai fanatisme atau solidaritas sosial. Konsep ini sangat sentral dalam pemikiran Ibn Khaldūn dan dapat digunakan untuk menjelaskan berbagai macam fenomena selama dalam koridor peradaban.

Ibn Khaldūn membagi peradaban menjadi dua jenis, yaitu peradaban nomaden (al-'Umrān al-Badawi) dan peradaban kota (al'Umrān al-Hadär). Ia kemudian memperkenalkan teori yang unik tentang kedua jenis peradaban ini. Menurutnya, peradaban bermula dari desa ketika kaum pedesaan yang masih segar turun gunung dan menguasai kota bahkan negara. Setelah berkembang dan merasa nyaman, mereka lalai, jenuh, dan akibatnya kehilangan identitas kepedesaannya dan kohesi sosialnya. Mereka lalu digantikan oleh sekelompok orang lain yang masih segar dari desa, demikian seterusnya. ${ }^{61}$

Ini artinya, masyarakat yang menggantikan satu sama lain adalah yang hidup dalam keadaan berpindah-pindah dari satu tempat ke tempat lain terutama dari desa ke kota. Kepindahan itu terkait dengan kebutuhan mereka yang paling mendasar yaitu makanan dan kebutuhan sehari-hari. Pada aspek ini, manusia dibedakan antara satu dengan yang lain atas dasar kebutuhan ekonomi. Seiring dengan perkembangan waktu, kaum pedesaan menginginkan kepastian dan kestabilan hidup. Mereka menciptakan kekuasaan antara lain dalam bentuk kota dan negara. Kehidupan kota ditandai dengan adanya buruh dan pertukaran saling menguntungkan antara satu orang dengan yang lain untuk menciptakan kesejahteraan. Perburuhan pada awalnya menciptakan kesejahteraan. Namun semakin kaya sebuah peradaban dan masyarakat, mereka justru berpikir untuk memperburuh orang lain demi kesejahteraan mereka sendiri. Dari sinilah tercipta perbedaan, kelas dan kemudian pertengkaran. Ikatan yang terbentuk dari kesukuan atau agama terancam.

Setiap masyarakat berada dalam ancamam untuk pecah bahkan punah, jika kebutuhan dan kepentingan ekonomi yang menjadi tujuannya. Namun Ibn Khaldūn tetap mengakui dimensi ini sebagai bagian penting dalam peradaban. Alasannya, pertama karena manusia adalah makhluk materi. Secara sosial-historis yang terus terjadi

${ }^{61}$ Ibn Khaldūn, Muqaddimah, 125. 
berulang-ulang dalam setiap peradaban adalah usaha manusia memenuhi kebutuhan hidupnya walau harus berhadapan dengan lawan. Dalam masyarakat tertentu, kebutuhan materil menempati urutan paling atas sebagai unsur utama terbentuknya peradaban. Kedua, interaksi sosial hanya bisa terjadi antara lain jika terdapat kepentingan materil antara beberapa pihak dalam masyarakat. Ibn Khaldūn menegaskan bahwa kebutuhan semacam ini mengharuskan manusia untuk bergaul dengan sesama. Mereka berinteraksi, menciptakan mekanisme, membagi tugas, menciptakan alat untuk menghasilkan makanan, dan menciptakan pekerjaan. Ini pada gilirannya melahirkan budaya, sesuatu yang dibutuhkan oleh peradaban agar lebih berwarna.

Selain kebutuhan materil, manusia juga memiliki kebutuhan untuk bertahan hidup dari bahaya. Seperti yang pertama, kebutuhan ini membuat manusia saling bergaul, membentuk kekuatan seperti negara, atau menyusun norma dan undang-undang untuk mengatur tatanan kehidupan. Di luar itu, ada pula kebutuhan ilmiah dan spiritual yang sifatnya lebih substansial dan mendasar. Kedua kebutuhan ini adalah prioritas dalam kehidupan manusia sebagai indifidu maupun kolektif. Ibn Khaldūn menempatkan ilmu dan spiritualitas sebagai supraktruktur, landasan bagi dimensi material peradaban.

Hubungan antara peradaban dengan ilmu dan spiritualitas sangat jelas; a) peradaban tidak akan dapat berkembang atau bertahan tanpa keduanya, b) peradaban tidak akan dapat membawa manfaat yang berarti jika tidak disinari oleh cahaya ilmu dan dibungkus dengan moralitas, dan c) cahaya ilmu dan moralitas adalah sumber bagi kesempurnaan dan kebahagiaan manusia. Ini sekaligus menjadi semacam antisipasi dari Ibn Khaldūn atas peradaban modern yang kini sedang berkembang. Peradaban modern yang kini mengalami defisit moral-walau unggul dari segi capaian materi dan pengembangan ilmu pengetahuan—sudah seharunya belajar dari tawaran masa lalu dan menyusun kembali peta jalannya agar tercapai pembangunan manusia yang lebih paripurna.

Tasawuf termasuk segelintir ilmu yang patut dipertimbangkan ketika peta jalan peradaban modern digambar ulang. Ilmu ini unggul dari segi ketersediaan kerangka epistemologis dan aksiologis. Ia menyediakan pedoman yang memadahi untuk kelangsungan hidup manusia. Ibn Khaldūn sudah memikirkan itu. Apa yang ia lakukan 
pada masanya tidak lain adalah untuk menawarkan tasawuf tidak saja sebagai dimensi moral atau intelektual bagi peradaban, namun juga sebagai salah satu tiang di dalamnya.

Tasawuf mengingatkan bahwa manusia dan masyarakat tidak saja digerakkan oleh kebutuhan apalagi kepentingan ekonomi semata. Masyarakat yang hanya mengejar kebutuhan materilnya berisiko mengalami krisis kejiwaan. Tasawuf hadir antara lain untuk melengkapi aspek materil peradaban dengan aspek spiritual. Peradaban Islam yang sudah berlangsung selama lebih dari 14 abad tidak pernah meninggalkan aspek spiritual ini. Nilai luhur yang terkandung di dalamnya membuat tasawuf bersama ilmu-ilmu lain yang mengajarkan nilai dan norma menjadi bagian tak terpisahkan dari setiap fase dalam peradaban Islam.

Seperti materi, tasawuf sebagai nilai tidak dapat bekerja tanpa penyangga atau mekanisme yang mendukungnya. Setiap nilai butuh dukungan untuk berfungsi dan bertahan. Ibn Khaldūn mengajarkan bahwa satu mekanisme yang dapat menyokong efektiftas nilai dalam bekerja adalah solidaritas sosial. Jangankan tasawuf, agama sekalipun butuh solidaritas sosial bahkan fanatisme untuk dapat hidup dan berkembang.

Setidaknya terdapat empat jenis solidaritas yang dapat diidentifikasi dari pemikiran Ibn Khaldūn, yaitu solidaritas material, biologis, ilmiah dan spiritual. Seiring dengan perkembangan tipologi masyarakat, dapat pula ditambah solidaritas nasional. Secara material, solidaritas adalah kecenderungan manusia menemukan platform bersama untuk memenuhi kebutuhan dasarnya seperti makanan dan keamanan. Solidaritas ini dibangun atas dasar kebutuhan material. Ia dapat melahirkan organisasi, kota hingga negara dengan berbagai perangkatnya seperti tata kelola organisasi dan moda-moda pertahanan yang dibutuhkan.

Solidaritas yang kedua-biologis—adalah platform kebersamaan yang dibangun atas dasar keturunan atau kadangkala kesukuan. Seperti jenis pertama, solidaritas ini berpotensi melahirkan kelompok atau entitas seperti organisasi, kota hingga negara. Sejarah Islam menjadi saksi bahwa solidaritas ini dapat berperan aktif melahirkan kekuatan, kemajuan dan peradaban.

Sementara itu solidaritas ilmiah dan spiritual adalah nilai yang lahir bukan semata karena kebutuhan dasar yang sifatnya sesaat melainkan karena didorong oleh kehendak menemukan kebenaran dan 
menegakkan kebaikan. Ada kesan Ibn Khaldūn tidak terlalu terang benderang ketika berbicara mengenai kedua jenis solidaritas ini. Namun gagasannya dapat dibaca dari ajaran mengenai peradaban pada satu sisi, dan solidaritas materi atau kesukuan pada sisi lain. Atas dasar premis yang sudah tersedia, tidak salah jika solidaritas ilmiah diartikan sebagai kebersamaan yang dibangun atas dasar nilai-nilai kebenaran ilmiah, sedang solidaritas spiritual adalah kebersamaan yang dibangun atas dasar nilai-nilai kebaikan dan moralitas. Solidaritas ilmiah memicu lahirnya aliran pemikiran, teori, wacana, ilmu, paradigma hingga tokoh pemikir, karya ilmiah dan lembaga pendidikan. Sedang solidaritas spiritual—dalam kasus Islam-melahirkan tarekat, mejelis taklim, mejelis zikir, pondok pesantren, lembaga pendidikan hingga karya ilmiah dan para tokoh sufi.

Ilmu dan spiritualitas berikut produk yang dihasilkannya sangat dikedepankan oleh Ibn Khaldūn. Keduanya adalah apa yang membuat manusia mencapai derajat kesempurnaannya. Tanpa keduanya, manusia akan menjadi seperti hewan walaupun meraih kesuksesan pada aspek materi. Manusia yang berorientasi semata pada capaian materi akan terseret pada pola hidup hedonistik atau gemar kemewahan. Kemewahan memicu praktik tidak terpuji seperti merampas dan menindas. Pesan Ibn Khaldūn tegas, "agar kehidupan terjaga manusia harus mengendalikan kecenderungan hewaninya dan mengatur solidaritas dengan sesamanya". 22 "Mengendalikan kecenderungan hewani" akan lebih efektif jika menggunakan peran para sufi yang memiliki otoritas moral. Sedang "mengatur solidaritas" akan lebih terstruktur jika dilakukan dengan menggunakan media ilmu dan memanfaatkan peran ulama.

Apa yang kita rumuskan di sini memang tidak selamanya eksplisit dalam pemikiran Ibn Khaldūn. Yang sedang kita usahakan adalah melebarkan gagasannya dari wilayah sosiologi agama ke arah sosiologi spiritual. Ini penting dan mendesak karena, a) Ibn Khaldūn layak mendapat apresiasi dengan cara mengembangkan gagasannya dari sudut pandang baru, b) pembacaan terhadap pemikiran Ibn Khaldūn terutama yang dilakukan oleh para sarjana Barat selama ini terlalu euro-sentris. Tidak sedikit di antara mereka yang menafsirkan

${ }^{62}$ Dikutip dari Muhsin Mahdi, Ibn Khaldūn's Philosophy of History (Chicago: The University of Chicago Press, 1964), 189. 
ajarannya secara materialistik. T.J de Boer contohnya. ${ }^{63}$ Pembacaan materialistiknya meniscayakan bahwa proses sejarah, cara hidup manusia, pola mereka bertahan, bagaimana mereka bekerja untuk mendapatkan makanan, cara mereka memimpin dan dipimpin, semuanya dikendalikan oleh dorongan untuk memenuhi atau bahkan memuaskan kebutuhan dan kepentingan materil semata.

Apa yang dirumuskan di sini adalah sebaliknya. Teori solidaritas spiritual mengharuskan bahwa proses sejarah dipandang sebagai bagian integral dari usaha manusia yang terus menerus untuk mencari dan menemukan Tuhan, membawa kebaikan dan mengusahakan keharmonisan. Manusia tidak selamanya tentang materi. Ia juga memiliki unsur batin yang hanya dapat dipenuhi dengan sentuhan spiritual. Peradaban yang diciptakan oleh manusia tidak boleh hanya diisi dengan muatan keduniaan saja. Kebahagian manusia tidak terletak pada kekayaannya saja, melainkan juga pada sikap, kepribadian, moralitas dan spiritualitasnya.

Dari sudut pandang seperti inilah tasawuf dan tarekat harus dibaca. Tidak benar jika tasawuf dan tarekat lahir hanya karena dorongan materil para sufi, seperti yang dikatakan oleh Maḥmūd Ismāī. ${ }^{64}$ Tasawuf dan tarekat lahir karena kebutuhan manusia akan pencerahan moral dan spiritual. Penjelasan lain seperti kebutuhan mencari kebenaran ilmiah dan agama, bisa saja diterima. Namun melihat sifat dasarnya, penjelasan solidaritas spiritual nampaknya lebih mendekati kebenaran secara metodologis.

Solidaritas spiritual dapat dipahami sebagai sifat bawaan manusia, seperti pada tataran materil, biologis dan ilmiah di mana setiap manusia memiliki sifat ingin bekerja sama pada tataran spiritual. Jenis solidaritas ini tidak selamanya ada dalam setiap masyarakat, sebagaimana jenis-jenis yang lain juga demikian. Pada masyarakat tertentu, solidaritas materil bisa jadi lebih menonjol dari pada solidaritas seperti agama. Faktor-faktor seperti sejarah, agama mayoritas, budaya hidup, pekerjaan yang diminati dan yang lain amat

${ }^{63}$ Lihat T.J De Boer, The History of Philosophy in Islam, terj. Edward R. Jones (New York: Dover Publication, 1967).

${ }^{64}$ Lihat Ismāīl, Süsiyuñlujīyà al-Fiker. Dalam karya ini Maḥmūd Ismāīl menggunakan pendekatan dan teori sosialisme-marxisme dalam membaca tasawuf. Hasilnya, sejarah tasawuf, proses berkembangnya, ajarannya, keberadaan tarekat beserta murshid dan lembaga pendidikannya, semuanya menurutnya dikendalikan oleh aspirasi dan dorongan materil. 
menentukan jenis solidaritas yang berlaku. Masyarakat materialistik sulit memiliki solidaritas spiritual, demikian pula sebaliknya.

Adalah dalam masyarakat sufi atau populer dengan sebutan tarekat, solidaritas spiritual dapat ditemukan dan berkembang dengan subur. Mejelis zikir dan kelompok pengajian pun memiliki kapasitas yang sama. Tarekat sebagai kolektifitas dibangun atas dasar kehendak untuk mencari pencerahan moral dan spiritual. Kadang pula motifasi untuk mencari kedamaian hidup merupakan dorongan mengapa seseorang bergabung dengan tarekat. Dalam tarekat—sebagaimana dalam mejelis zikir dan pengajian-solidaritas materil nyaris tidak dapat berkembang. Hubungan antar-murid pada satu sisi, dan antara murid dengan guru pada sisi lain terbentuk dari kehendak bersama untuk menebar kebaikan. Sejarah sudah membuktikan bahwa tarekat tertentu tidak dapat bertahan dan hilang, tidak lain karena kegagalannya membangun solidaritas spiritual ini. Ada pula tarekat yang mati karena unsur spiritualitasnya terkikis oleh mental dan perilaku materialistik pengikutnya atau bahkan murshid-nya.

Dengan demikian, kelahiran tarekat, dinamika perkembangan dan pertahanannya dapat dijelaskan dengan teori solidaritas spiritual. Rasa memiliki atau sentimen kelompok yang kuat sangat berperan dalam tarekat. Bagi Ibn Khaldūn, kekompakan dan kebersamaan yang muncul dari rasa memiliki adalah ukuran apakah sebuah masyarakat dan kelompok bisa makmur dan bertahan atau tidak. Jika dalam teori biologi, kebersamaan bisa dibangun atas dasar keturunan; dalam teori ekonomi bekerja sama dapat dicapai karena adanya kebutuhan dasar hidup; dalam teori evolusi kelangsungan hidup kelompok atau masyarakat dapat terjadi karena adanya timbal balik, maka dalam teori spiritual keberlangsungan masyarakat dan kemajuannya dapat terwujud karena adanya komitmen meraih kebaikan.

Ilmu antropologi sudah pernah mencoba menunjukkan bahwa pada dasarnya manusia memiliki kecenderungan spiritual untuk mencapai derajat kesempurnaan diri yang lebih tinggi. Ilmu biologi juga mengajarkan demikian. Kedua ilmu ini lalu sepakat bahwa untuk mencapai kesempurnaan, harus ada kebersamaan. Dalam kebersamaan, manusia bersedia berkorban demi kepentingan orang lain walau harus mengorbankan kepentingan diri sendiri (altruisme). Dalam teori biologis altruisme berlaku dalam kelompok yang anggotanya berasal dari keturunan yang sama. Dalam teori antropologis, ini berlaku dalam sebuah masyarakat dengan identitas 
sosial yang sama. Dalam teori ekonomi, ini berlaku bagi masyarakat yang memiliki kepentingan materil yang sama. Dalam teori spiritual, ini juga dapat berlaku dalam sebuah kelompok dengan tujuan dan pandangan hidup spiritual yang sama.

Apa yang diajarkan oleh ilmu biologi dan antropologi bahkan ekonomi adalah pengantar yang baik untuk mengembangkan teori solidaritas spiritual. Perspektif spiritual tentang solidaritas dapat menutupi kekurangan yang ditinggalkan oleh perspektif yang lain. Biologi hanya menekankan pada bentuk kerjasama yang dibangun atas dasar hubungan darah saja. Bahkan ada aliran dalam ilmu ini yang mengakui bahwa hanya hubungan sedarah saja yang dapat menjamin terciptanya stabilitas dalam kelompok. Hubungan yang lain mereka anggap sia-sia. Alasannya, karena masyarakat yang memiliki hubungan sedarah lebih siap untuk membangun kebersamaan atas dasar pengorbanan timbal balik. Ada kalanya perspektif antropologis menyepakati teori ini, namun menerapkannya dalam konteks masyarakat.

Ini sulit diterima karena kebersamaan juga terbukti dapat dibangun di atas pondasi lain seperti agama, nasionalisme dan juga spiritualitas. Sebagai spiritualitas, tasawuf bahkan memiliki nilai yang tidak dimiliki oleh yang lain, yaitu penekaan pada empati. Empati sebagai rasa dan intuisi adalah unsur integral dalam setiap spiritualitas. Empati adalah perasaan ingin berbagi, merasa membutuhkan kerjasama orang lain, berbagi harapan, kebahagiaan bahkan kesengsaraan dan kesulitan hidup atau memainkan peran yang seharusnya dimainkan oleh orang lain, memikul atau mengurangi beban orang lain. Dalam tasawuf, empati diajarkan antara lain melalui konsep uns (kelembutan) dan mahabbah (cinta kasih).

Pada akhirnya, menjelaskan tasawuf dan tarekat secara sosiologis memang bukan tanpa konsekuensi apalagi jika merujuk kepada pemikiran Ibn Khaldūn. Bagi sebagian orang, Ibn Khaldūn tidak pernah berpikir tentang sosiologi tasawuf. Fuad Baali termasuk dalam daftar orang yang pasti akan menolak gagasan ini. Secara tegas ia menulis:

Ibn Khaldūn meyakini bahwa masyarakat dan juga alam diatur oleh proses dialektis. Namun ia melihat bahwa dialektika tasawuf terlalu bersifat spiritualistik dan idealistik sehingga sulit diterapkan dalam proses sosial. Karena itu (agar dapat bernuansa sosiologis) Ibn Khaldūn memperlakukan tasawuf dengan cara melepaskannya dari 
corak spiritualnya dan mewarnainya dengan corak materialistik dan sosiologis. ${ }^{65}$

Yang ingin disampaikan oleh Fuad Baali adalah bahwa Ibn Khaldūn memiliki dua persepsi tentang tasawuf. Pertama, secara normatif tasawuf adalah dimensi moral-spiritual dalam Islam. Kedua, ia menawarkan bahwa dimensi moral-spiritual ini harus dikorbankan atau dikosongkan jika tasawuf ingin dijelaskan secara sosiologis. Jika sudah kosong, maka kemudian diisi dengan nuansa sosialmaterialistik.

Cara ini bisa saja benar secara akademis. Namun sudut pandang Baali seperti T.J de Boer terlalu materialistik. Apa yang ia hasilkan kemudian adalah penyempitan atas gagasan Ibn Khaldūn. Fuad Baali tidak pernah menyadari bahwa dalam ajaran Ibn Khaldūn, tasawuf adalah langkah awal menuju kehidupan yang lebih luas dalam masyarakat. Yang patut diketahui adalah Baali sendiri merupakan sosok yang tidak pro-tasawuf. Ia pernah menulis, "peradaban bukan tempat bagi orang-orang yang bermental pasrah". ${ }^{66}$ Dengan mengutip Sorokin ia menulis, "sebuah peradaban menjelang kehancurannya cenderung merapat kepada mistisisme atau gnostisisme" ${ }^{67}$

Yang kita lakukan di sini adalah kebalikan dari apa yang dilakukan oleh Baali, yaitu menghindari penyempitan dan mengusahakan perluasan atas gagasan Ibn Khaldūn tentang tasawuf. Langkah ini pernah dilakukan oleh Ali Omlil ketika membaca tasawuf Ibn Khaldūn sebagai wacana sejarah. Ia memperlebar pembacaannya atas tasawuf dengan cara, "memaknainya secara lebih luas karena peran pentingnya yang tidak terbatas pada persoalan agama dan spiritualitas". ${ }^{68}$ Omlil lalu menegaskan, "tasawuf lebih identik dengan usaha memperbaiki keadaan umat dari pada usaha memperbaiki keadaan batin seseorang". ${ }^{9}$

\section{Penutup}

Tasawuf tidak dapat dipisahkan dari aspek normatif dan spiritualnya. Usaha untuk menafsirkan ilmu ini secara sosiologis tidak dapat dilakukan dengan cara mengosongkannya dari kedua unsur ini.

\footnotetext{
${ }^{65}$ Fuad Baali, Society, State, and Urbanism: Ibn Khaldūn's Sociological Thought (New York: SUNY Press, 1988), 71.

${ }^{66}$ Ibid., 72.

${ }^{67}$ Ibid., 78.

${ }^{68}$ Omlil, al-Khitäb al-Tärìkhì, 174.

${ }^{69}$ Ibid., 175.
} 
Apa yang dilakukan oleh Ibn Khaldūn sudah benar ketika ia mencoba memberi warna sosiologis dalam tasawuf tanpa mengorbankan kedua dimensinya yang paling fundamental.

Ibn Khaldūn menawarkan beberapa prinsip umum yang dapat dimanfaatkan sebagai kerangka untuk menafsirkan tasawuf secara sosiologis. Prinsip umum itu adalah bagian integral dari konsep alUmrān, yaitu a) bahwa masyarakat adalah sebuah keniscayaan, b) manusia dan masyarakat saling terkait, dan c) manusia dan masyarakat memiliki kebutuhan spiritual. Ibn Khaldūn telah berusaha menunjukkan pandangannya pada persoalan pertama dan kedua, namun tidak banyak bicara mengenai persoalan ketiga. Ia seolah menyerahkan persoalan ini kepada generasi berikut untuk menjelaskannya.

Penjelasan mengenai kebutuhan spiritual manusia dan masyarakat (persoalan ketiga) dapat dilakukan dengan cara memperluas prinsip umum yang telah ia tawarkan seputar persoalan pertama dan kedua. Konsep paling utama yang Ibn Khaldūn gagas terkait dengan masyarakat dan mekanisme keberlangsungannya melalui solidaritas dan kohesi sosial dapat diterapkan kepada masyarakat sufi yang diwakili oleh tarekat.

Sifat dasar sebuah masyarakat tetap sama apapun nama dan labelnya, yaitu adanya kehendak untuk berkelompok dan bekerjasama. Yang membedakan adalah-Ibn Khaldūn mengajarkan-motif dan tujuannya. Ada masyarakat yang terbentuk karena dorongan materil, ada pula karena alasan lain seperti kesukuan, keturunan, politik dan tentu saja spiritual. Nilai yang dikembangkan dalam setiap masyarakat berikut mekanisme yang bekerja untuk mempertahankan dan mengembangkan diri sangat tergantung pada motif dan tujuan masyarakat itu. Yang pasti, semua nilai dan mekanisme, seperti solidaritas dapat bekerja dalam setiap masyarakat jika ada dorongan dan kehendak di dalamnya.

Pemikiran sosiologis Ibn Khaldūn membahas masyarakat, bukan individu. Individu hanya dibahas sebagai bagian dari masyarakat. Ini penting, sebab berlawanan dengan sifat dasar tasawuf yang mementingkan indifidu bukan masyarakat. Karena itu agar tujuan menafsirkan tasawuf secara sosiologis dapat tercapai, maka makna tasawuf harus diperluas dari sekadar ilmu tentang indifidu menjadi tentang masyarakat. 
Pada sisi lain, pemahaman kita tentang masyarakat dan batasanbatasannya harus dikembangkan seiring dengan perubahan yang serba cepat dan masif pada peradaban modern umat manusia. Jika ada yang memahami masyarakat dan batasannya secara biologis, ekonomi, politik, budaya, bahasa bahkan kesukuan, maka sangatlah penting untuk memahaminya pula secara moral-spiritual. Jika ilmu-ilmu modern seperti sosiologi, antropologi hingga psikologi dan biologi dibenarkan menawarkan perspektif mereka tentang apa itu masyarakat dan batasannya, maka tasawuf sebagai ilmu mestinya juga dibenarkan melakukan hal yang sama. Sosiologi tasawuf dihadirkan antara lain untuk tujuan ini; menawarkan sebuah perspektif bahwa masyarakat bisa terbentuk karena dorongan moral-spiritual dan tidak selalu atas dasar materil, biologis atau kepentingan kesukuan.

\section{Daftar Rujukan}

Alatas, Syed Farid. Applying Ibn Khaldun: The Recovery of a Lost Tradition in Sociology. London dan New York: Routledge, 2014.

-----. Ibn Khaldun. Oxford: Oxford University Press, 2012.

'Ațīyah (al), Jalāl. "Ṭaha Ḥusayn wa Ibn Khaldūn fị Qafas al-Ittihām”, al-Sharq al-Awsat, 1 November, edisi 9470, 2004.

'Aț̣ār (al), Khālid. "Kata Pengantar", Muqaddimah Ibn Khaldūn. Beirut: Dār al-Fikr, 1998.

Azraq (al), Abū 'Abd Allah b. Badā'i' al-Silk fi Ṭabā'i' al-Mulk, 'Alī Sāmī al-Nashshār. Kairo: Dār al-Salām, 1990.

Baali, Fuad. Society, State, and Urbanism: Ibn Khaldūn's Sociological Thought. New York: SUNY Press, 1988.

Barnes, Harry dan Becker, Howard. Social Thought: from Lore to Science.

Washington: Heath and Company, 1938.

Barzinji, Mariwan Nasradeen Hasan. The Image of Modern Man in T.S Eliot's Poetry. Bloomington: Authorhouse, 2012.

Black, Antony. History of Islamic Political Thought. Edinburg: Edinburg University Press, 2011.

Boer, T.J De. The History of Philosophy in Islam, terj. Edward R. Jones. New York: Dover Publication, 1967.

Collins, Randall. The Sociology of Philosophies: A Global Theory of Intellectual Change. Edisi keempat. Cambridge, Massachusetts dan London: The Belknap Press of Harvard University Press, 2002. 
Enan, Muhammad Abdullah. Biografi Ibn Khaldūn: Kebidupan dan Karya Bapak Sosiologi Dunia, terj. Machnun Husein. Jakarta: Zaman, 2013.

----. Ibn Khaldūn: His Life and Works. Kuala Lumpur: The Other Press, 2007.

Fleet, Kate. The Cambridge History of Turkey, Suraiya N. Faroqhi (ed.). Cambridge: Cambridge University Press, t.th.

Fromherz, Allan James. Ibn Khaldun: Life and Times. Edinburg: Edinburg University Press, 2010.

Galal, Abdel Fattah. "Taha Hussein", Prospect: The Quarterly Review of Comparative Education, Vol XXIII, No 3/4, 1993.

Gurkan, S. Leyla. "Celebi, Katib Mustafa b Abdullah", dalam Oliver Leaman (ed.), The Biographical Encyclopeia of Islamic Philosophy. London: Bloomsbury, 2014.

Halabi, Haji Khalīfah Musțafā b. 'Abd Allah Kātib. Kashf al-Zunūn 'an Asam al-Kutub wa al-Funūn, 'Abd al-Qādir 'Ațā' (ed.). Beirut: Dar al-Kutub al-Ilmīyah, 2006.

Husayn, Taha. Falsafah Ibn Khaldūn al-Ijtimāàyah: Taḅlìl wa Naqd, terj.

Muhammad 'Abd Allah Enan. Mesir: Maṭba'at al-I'timād, 1925.

Irwin, Robert. Ibn Khaldun: an Intellectual Biography. Princeton: Princeton University Press, 2018.

Ismāīl, Maḥmūd. Sūsiỳulujizyaa al-Fìkr al-Islāmì. London, Beirut, Kairo: Sinā li al-Nashr, 2000.

Khaldūn, Ibn. Muqaddimah. Beirut: Dār al-Fikr, 1998. Shifä' al-Säil. Istanbul: t.tp., 1985.

Lewis, Bernard. "Ibn Khaldun in Turkey", dalam Jesus Viguera Mollins (ed.), Ibn Khaldin: The Mediterranean in the 14th Century (Rise and Fall of Empires). Andalusi: Jose Manuel Lara, 2006.

Luṭfí, 'Umar Musțafā. "Muḥammad 'Abd Allah Enan”, Majalab Hilāl, Edisi Januari, 1985.

Maghribī, 'Abd al-Ghanī. al-Fiker al-Ijtimā's 'ind Ibn Khaldūn. Aljazair: Diwan al-Maṭū'at al-Jāmi'īyah, 1988.

Mahdi, Muhsin. Ibn Khaldun's Philosophy of History. Chicago: The University of Chicago Press, 1964.

Maqrizī (al), Taqiy al-Dīn. al-Muqaffa al-Kabìr, Muhammad 'Uthmān (ed.). Beirut: Dār al-Kutub al-Ilmīyah, 2005.

----. Ighäthat al-Ummah bi Kashf al-Ghummah, Karām Hilmī Farhat (ed.). Kairo: 'Ayn, 2007. 
Morris, James Winston. “An Arab Machiavelli? Rhetoric, Philosophy, and Politics in Ibn Khaldūn's Critique of Sufism", Harvard Middle Eastern and Islamic Review, Vol. 8, 2009.

Nasr, Seyyed Hossein. Islam and the Plight of Modern Man. Chicago: ABC International Group, 2001.

Omlil, Ali. al-Khitāa al-Tārikkhi: Dirāsah li Manhajīyat Ibn Khaldūn. Beirut: Ma‘had al-Inmā’ al-'Arabī, 1997.

Rabbat, Nasser. "Was al-Maqrizī's Khitat a Khaldunian History?”, Der Islam, Vol. 89, No. 1-2, November 2012.

Riyadi, Abdul Kadir. Arkeologi Tasawnf. Bandung: Mizan, 2016.

Syrier, Miya. "Ibn Khaldūn and Islamic Mysticism", Islamic Culture, Vol. 21, 1947.

Wardī (al), 'Alī. Mantiq Ibn Khaldūn fì Daw' Hadāratih wa Shakbshìyatih. Beirut: Dār Kufan, 1994. 